\title{
Exit, Voice, and Political Change: Evidence from Swedish Mass Migration to the United States
}

\section{Mounir Karadja}

Uppsala University

\section{Erik Prawitz}

Research Institute of Industrial Economics

\begin{abstract}
We study the political effects of mass emigration to the United States in the nineteenth century using data from Sweden. To instrument for total emigration over several decades, we exploit severe local frost shocks that sparked an initial wave of emigration, interacted with within-country travel costs. Our estimates show that emigration substantially increased the local demand for political change, as measured by labor movement membership, strike participation, and voting. Emigration also led to de facto political change, increasing welfare expenditures as well as the likelihood of adopting more inclusive political institutions.
\end{abstract}

\section{Introduction}

Starting in the mid-nineteenth century, the Age of Mass Migration saw 30 million Europeans leave their home countries for the United States.

We are indebted to the editor Jesse Shapiro as well as five anonymous reviewers for many helpful comments and suggestions. We thank Torsten Persson, David Strömberg, Ran Abramitzky, Ingvild Almås, Konrad Burchardi, Davide Cantoni, Björn Tyrefors Hinnerich, Supreet Kaur, Suresh Naidu, Arash Nekoei, Peter Nilsson, Maria Petrova, Per PetterssonLidbom, Imran Rasul, Jakob Svensson, Anna Tompsett, and numerous seminar and conference participants for helpful discussions. We acknowledge funding from Handelsbanken's Research Foundations. Data are provided as supplementary material online.

Electronically published June 18, 2019

[ Journal of Political Economy, 2019, vol. 127, no. 4]

(c) 2019 by The University of Chicago. All rights reserved. 0022-3808/2019/12704-0010\$10.00 
Through social and family ties, early movers spurred additional emigrants over time, leading to a long-lasting pattern of chain migration (Hatton and Williamson 1998). What were the political repercussions at the origin of this shock to ordinary citizens' mobility? Consider figure 1, which plots the relationship between a measure of labor's bargaining strength-the share of workers in 2000 who were unionized - and the size of the US emigrant stock in 1910. Across 29 OECD countries, the figure displays a positive relationship between modern unionization and historical migration. ${ }^{1}$ Countries with large US populations, such as Italy, Germany, Ireland, and Sweden, have considerably higher unionization rates than lowemigration countries such as Spain, France, and Poland. The Age of Mass Migration also coincided with a notable surge in democracy, with many European states adopting democratic institutions and expanding suffrage (Moses 2011). These correlations suggest that the US policy of open borders during the nineteenth century may have influenced political development in the Old World. This paper is devoted to testing this hypothesis.

We focus our attention on Sweden, which had one of the highest exit rates in the period. A quarter of its population, or about 1.3 million citizens, emigrated in the course of 60 years, mainly to the United States. ${ }^{2}$ This coincided with a period of political development in Sweden. The dominant force in Swedish twentieth-century politics, the Social Democratic Party, and the powerful labor union movement were founded during the period and became key actors in reforming Swedish policy and political institutions.

It is unclear how emigration related to this development, however. Theoretically, the effect of emigration on an autocratic origin country is ambiguous. Hirschman (1970) hypothesized that if political dissidents choose to exit the country rather than to push for reforms, the result may be a lower level of voice for political development. On the other hand, Hovde (1934) argues that the Age of Mass Migration put labor in a stronger bargaining position by improving workers' outside options and making emigration a credible threat. As early as the eighteenth century, the French economist and statesman Anne-Robert-Jacques Turgot predicted that "the asylum which [the American people] opens to the oppressed . . . will oblige the European governments to be just and enlightened" (quoted in Hirschman $[1978,98]) .{ }^{3}$ Observing the wave of European democratization after

\footnotetext{
${ }^{1}$ In online app. sec. A.9, we show that this correlation is robust to controlling for a set of covariates, including GDP and schooling length. The correlation is also robust to replacing emigration to the United States with emigration to all destinations for countries for which such data are available.

${ }^{2}$ The net annual migration rate during $1870-1910$ was about -4.2 per 1,000 inhabitants. By comparison, the average rate in the Old World was about -3.08 , with Ireland, Italy, and Norway displaying rates of $-11.24,-9.25$, and -5.25 , respectively ( Taylor and Williamson 1997).

${ }^{3}$ On a related note, referring to the black out-migration from the US South, Myrdal (1944) pointed out that it would be "one of the surest ways" of pushing the white elites
} 


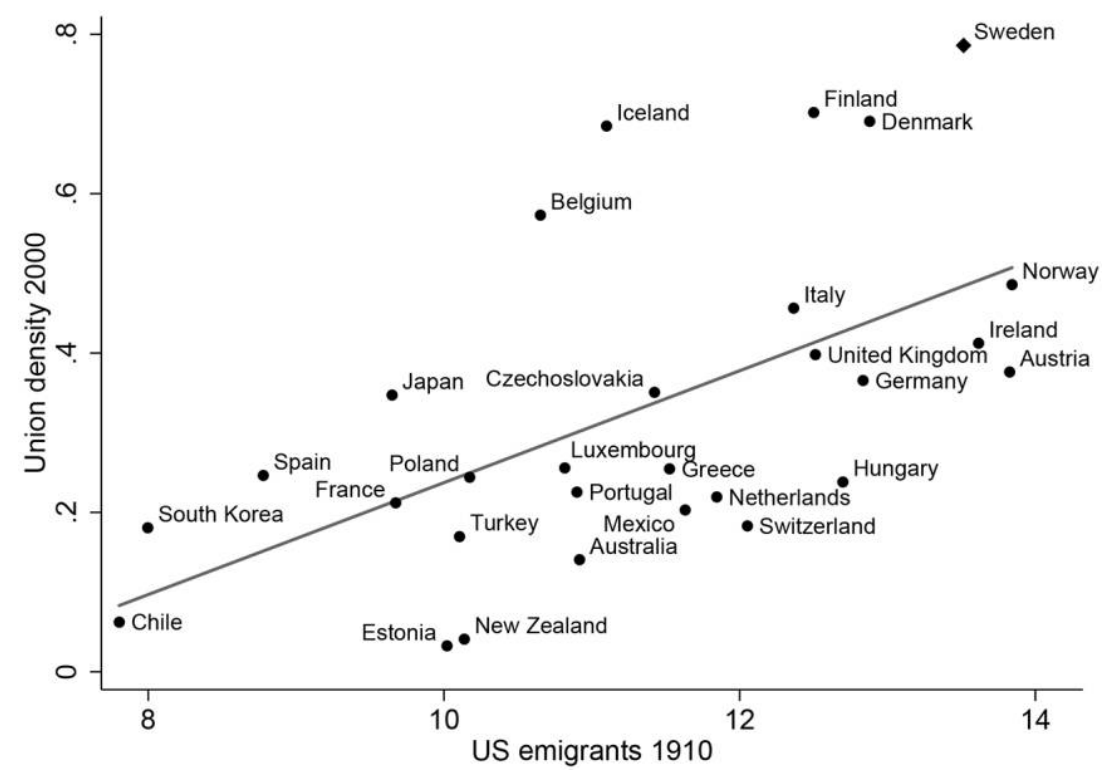

FIG. 1.-Emigration and trade union density across OECD countries. This figure displays the cross-country relationship between trade union density in the year 2000 and the log number of US emigrants as of 1910. Both variables are the residuals after being regressed on $\log$ population in 1820 . Means of the unadjusted variables have been added for scale. A regression line based on the underlying data is displayed, also controlling for the 1820 population. Trade union density is defined as the share of wage and salary earners that are members of a trade union and is provided by the OECD. Trade union density for Czechoslovakia is defined as the mean of values from the Czech Republic and Slovakia.

the mass migration era, Hirschman (1978) later argued that exit may act as a complement to the expression of voice rather than a substitute.

We deploy a wide range of data sources spanning the mass migration period to study the long-term political effects of emigration across Swedish municipalities. Our main outcome is membership in the local labor movement. We also estimate the effect of emigration on local welfare policy and choice of political institutions.

To establish causality, we leverage the fact that Sweden's mass emigration was sparked by a series of severe agricultural shocks in the 1860s, which were caused by unusually cold temperatures (Sundbärg 1913; Barton 1994; Beijbom 1995). Using daily temperature data from this period, we measure the incidence of growing season frost shocks during 186467 , just prior to the onset of early mass migration. We then construct an instrument that captures only variation in emigration push factors: the

to give more consideration to the remaining southern blacks. Analyzing the relation between black mobility and education spending in the US South, Margo (1991) concludes that the threat of exit placed limits on local government discrimination. 
interaction between frost shocks in 1864-67 and the proximity to the nearest of the two major emigration ports. ${ }^{4}$ Using only the interaction term as our instrument allows us to control for both port proximity and frost shocks themselves, which avoids confounding direct effects of severe economic shocks on political outcomes. Importantly, we show that Swedish emigration was highly path dependent and that the instrument thus strongly predicts cross-sectional variation in total emigration across the 50-year sample period. ${ }^{5}$ The instrument passes several exogeneity tests, including balance of predetermined covariates and placebo treatments using shocks in other periods. An alternative instrument using shocks occurring in the nongrowing seasons of 1864-67 has no effect on emigration or second-stage outcomes.

Our results show that municipalities that experienced more emigration during the Age of Mass Migration exhibit significantly stronger demand for political change. Membership in the local labor movement is significantly higher starting in 1900, and so is participation in a major general strike in 1909. Furthermore, we find an increased voter turnout in national elections from 1911 to 1921, as well as higher vote shares for left-wing parties in those same elections. ${ }^{6}$ Rather than inhibiting the use of voice, higher emigration appears to have brought about more political organization and left-wing preferences among ordinary citizens, indicating an improved bargaining position vis-à-vis local elites. We also find that the stronger left-wing preferences persist in present-day elections, over a century after the start of Swedish mass migration. ${ }^{7}$

Emigration also affected local policy and political institutions. Reflecting the preferences of the labor movement, local politics became more redistributive and inclusive. Welfare expenditures, both total and per capita, were significantly higher in municipalities with more emigration, both before and after the introduction of democracy in 1919. Since local political power was biased in favor of wealthier citizens prior to 1919, the results are consistent with the hypothesis that concessions were made by elites in favor of citizens, although we cannot rule out that other mechanisms play a role.

\footnotetext{
${ }^{4}$ See, e.g., Sjaastad (1962), Quigley (1972), and Morten and Oliveira (2018) regarding the importance of distance and other travel costs for migration decisions.

5 High degrees of path dependence in migration patterns are a canonical finding in the migration literature and have been found in numerous settings; see, e.g., Massey et al. (1993), Hatton and Williamson (2005), McKenzie and Rapoport (2007), Bryan, Chowdhury, and Mobarak (2014), and Giulietti, Wahba, and Zenou (2014).

${ }^{6}$ This is consistent with recent US evidence that unions affect members' political preferences (Kim and Margalit 2016).

7 These findings are in line with studies in economics and political science that have found political preferences to be persistent within individuals as well as correlated across generations; see, e.g., Alford, Funk, and Hibbing (2005), Jennings, Stoker, and Bowers (2009), and Madestam and Yanagizawa-Drott (2012).
} 
At the time, local governments were organized as either direct or representative democracies. Recent evidence has shown that local representative democracies provided higher welfare expenditures, as direct democracies were more easily captured by local elites (Hinnerich and Pettersson-Lidbom 2014). We find that municipalities with greater emigration more often introduced representative democracy between 1919 and 1938.

Determining the mechanisms behind these findings that span several decades is hard. Nevertheless, we use the data available to us to evaluate the plausibility of several potential explanations. Drawing on Kapur and McHale (2005), we consider four broad channels. First, easier access to emigration can raise the outside options of those left behind, influencing bargaining between citizens and elites. Second, emigration may elicit local economic responses that in turn cause political change. Third, the selection of migrants may change the composition of people who remain in Sweden. Fourth, emigrants may transmit American attitudes to their countrymen at home.

We argue that better outside options may be a contributing mechanism. It is well known that Swedes with social networks overseas had lower moving costs and were more likely to emigrate later on themselves (see, e.g., Runblom and Norman 1976; Beijbom 1995). Given the greater living standards in the United States, outside options were thus better in locations with a stronger history of emigration. We find that such locations have not only more emigrants later on but also less internal migration. ${ }^{8}$

Accounts by historians suggest that the emigration option played an important role in empowering labor unions. As union membership was routinely punished by employers, the option to emigrate appears to have reduced the downside risk of organizing labor (Rondahl 1985). At the same time, unions encouraged emigration (Beijbom 1995), and the improved outside options for citizens may have caused economic and political elites to be more responsive to citizens' demands (Hovde 1934). In fact, we find suggestive evidence of emigration leading to higher wages.

Turning to economic channels, we find that besides increasing lowskilled wages, emigration positively affected the share of workers employed in the burgeoning industrial sector. These results are in line with Ljungberg's (1997) thesis that emigration raised wages and therefore incentivized the modernization of the Swedish economy in the late nineteenth century. Consistent with this, we also find evidence of substitution away from labor and toward capital in agriculture. ${ }^{9}$ The growing industrial

${ }^{8}$ This is consistent with contemporary evidence suggesting that internal migration was often disregarded in municipalities with a strong history of US emigration (see, e.g., Nelson 1909).

${ }^{9}$ In related work, Andersson, Karadja, and Prawitz (2017) also find higher rates of innovation as measured by technological patents. 
sector hence may have played a role in creating the basis for labor organizations to form. However, the shift in employment toward industry cannot by itself explain our results on labor movement membership and strike participation, as these hold even when expressed per industrial worker rather than per capita.

We evaluate migrant self-selection in two main ways. First, a bounding exercise shows that the positive and significant effect on the labor movement holds even under the assumption that all emigrants would not have been members. Second, we find small and insignificant effects of emigration on demographic differences in terms of sex ratios, marriage rates, rates of in-migration, and voting eligibility. High-emigration municipalities are, however, younger on average. Consequently, while selection may play a role in explaining our results, it is unlikely to explain them entirely.

Finally, we evaluate the potential transfer of American attitudes to origin areas. While the influence of Scandinavian labor organizers on American unions is well documented (Nordahl 1994; Bengston and Brook 1999), little evidence suggests that the Swedish labor movement was influenced by the United States. As an indirect test, we study how emigration affected two types of organizations that were strongly influenced by the United States - nonstate free churches and temperance lodges-finding no positive effects on membership rates.

Our study relates to a nascent empirical literature on the political effects of emigration in origin countries. ${ }^{10}$ Kapur (2014) provides a recent survey of the literature. Several papers have studied the effects of migration to more democratic countries, finding a positive effect on democratization (Spilimbergo 2009; Docquier et al. 2016; Mercier 2016), political participation (Chauvet and Mercier 2014), political institutions (Beine and Sekkat 2013), demand for political and social change (Batista and Vicente 2011; Tuccio, Wahba, and Hamdouch 2016), and voting for an opposition party (Pfutze 2012; Barsbai et al. 2017) and a negative effect on conflict prevalence (Preotu 2016).${ }^{11}$ By contrast, Anelli and Peri (2017) find that emigration during the Great Recession hampered political change in Italy. Migrant remittances have been found to affect home country political institutions in both positive and negative ways (Ahmed 2012, 2013; Pfutze 2014; Escriba-Folch, Meseguer, and Wright 2015).

We make three contributions to this literature. First, we exploit plausibly exogenous variation to identify the causal effects of emigration on political outcomes. Second, while the existing literature emphasizes the

\footnotetext{
10 There is also a theoretical literature linking political and economic repression to migration (Docquier and Rapoport 2003; Mariani 2007; Wilson 2011).

${ }^{11} \mathrm{Li}, \mathrm{McH}$ ale, and Zhou (2017) also study the effects of emigration on domestic institutions by human capital level of emigrants.
} 
transfer of attitudes from host to origin countries, we find some evidence against this and explore other mechanisms such as improved outside options of connected citizens. Third, we not only show how emigration affects the demand for political change but also track its effects on actual political change in terms of local policies and institutions.

The effect of mass migration on the United States in this period has been extensively studied. Abramitzky and Boustan (2017) provide an overview. We contribute to this literature by focusing on the effect of the Age of Mass Migration on origin countries, where research is more lacking.

We also relate to the literature on institutions in economic development, and political change in particular. ${ }^{12}$ A growing set of papers investigate the effects of trade on institutional change (Acemoglu, Johnson, and Robinson 2005; Puga and Trefler 2014; Dippel, Greif, and Trefler 2015; Sánchez de la Sierra 2017). The importance of factor mobility for institutional change has been studied theoretically, though mainly focusing on the mobility of capital rather than labor (Boix 2003).

The remainder of the paper proceeds as follows. Section II provides an overview of Swedish mass emigration and describes the historical evidence regarding its onset in the 1860s. The labor movement and its relationship to emigration are also described. Section III describes our data. Section IV introduces the econometric framework and our identification strategy. Sections V-VII discuss the first-stage relationship as well as the effects of emigration. Section VIII discusses underlying mechanisms. Section IX performs robustness checks and placebo tests. Finally, Section $\mathrm{X}$ discusses our results and concludes the paper.

\section{Background}

\section{A. Swedish Mass Emigration to the United States}

Starting in 1850, the Age of Mass Migration saw 30 million Europeans settle in the United States. Under its policy of free immigration, individuals from across the world were allowed permanent residency in the United States. Sweden was one of the biggest sending countries in per capita terms, along with Ireland, Italy, and Norway (Taylor and Williamson 1997). A total of 1.3 million Swedes emigrated from 1860 to 1920 , corresponding to one-quarter of the average population over the period.

Swedish emigration took off abruptly at the end of the 1860s. In the peak year of 1869 alone, nearly 1 percent of the population emigrated, and in the years between 1867 and 1879, 200,000 Swedes left their home country. We refer to the sharp increase in emigration in 1867-79 as the

12 There is a large literature investigating transitions into and from democracy at the national level. See Persson and Tabellini (2009) and studies cited therein. 


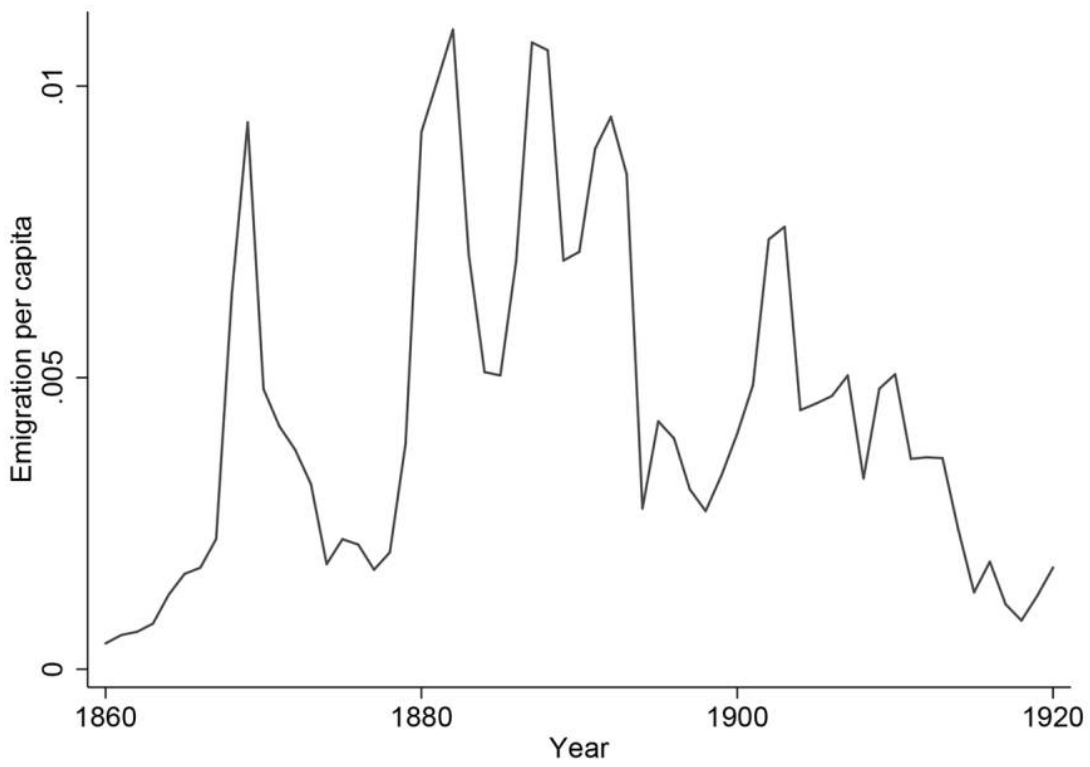

FIG. 2.-Emigration flows, 1860-1920. This figure displays aggregate emigration flows per year between 1860 and 1920. We label emigration during the 1867-79 period the first wave of mass emigration. Later waves, during the 1880 s and early 1900 s, are also visible. Mass migration from Sweden ended in the 1920s, as the United States enacted immigration quotas.

first wave of mass emigration. ${ }^{13}$ The spike of the first wave is evident in figure 2, which displays per capita emigration rates over the period. The causes and the timing of the Swedish mass emigration episode have been widely discussed by historians. Central to the existing accounts is the series of bad harvests in the 1860 s, caused by unusually poor weather conditions, which led to widespread poverty and served as a catalyst for emigration on a large scale (see, e.g., Sundbärg 1913; Barton 1994; Beijbom 1995). In particular, cold weather led to a high incidence of frost as nighttime temperatures fell below 0 degrees Celsius, even during the regular growing season. The spring of 1867 saw the most extreme weather, in some cases lasting well into the summer months. ${ }^{14}$

The famine years were particularly harshly felt because agriculture was the main source of food and income for most citizens: in 1865, 83 per-

\footnotetext{
${ }^{13}$ Earlier emigration was uncommon: in 1865 the Swedish American population was estimated at 25,000 (Barton 1994).

${ }_{14}$ The month of May 1867 is the coldest known May in Swedish history, and the meteorological summer $\left(5\right.$ days in a row with temperatures above $10^{\circ} \mathrm{C}$ ) started only in mid-June in many parts of Sweden (Swedish Meteorological and Hydrological Institute 2013). In Finland, the temperatures observed during the spring of 1867 have a one in 500 probability of occurring (Jantunen and Ruosteenoja 2000).
} 


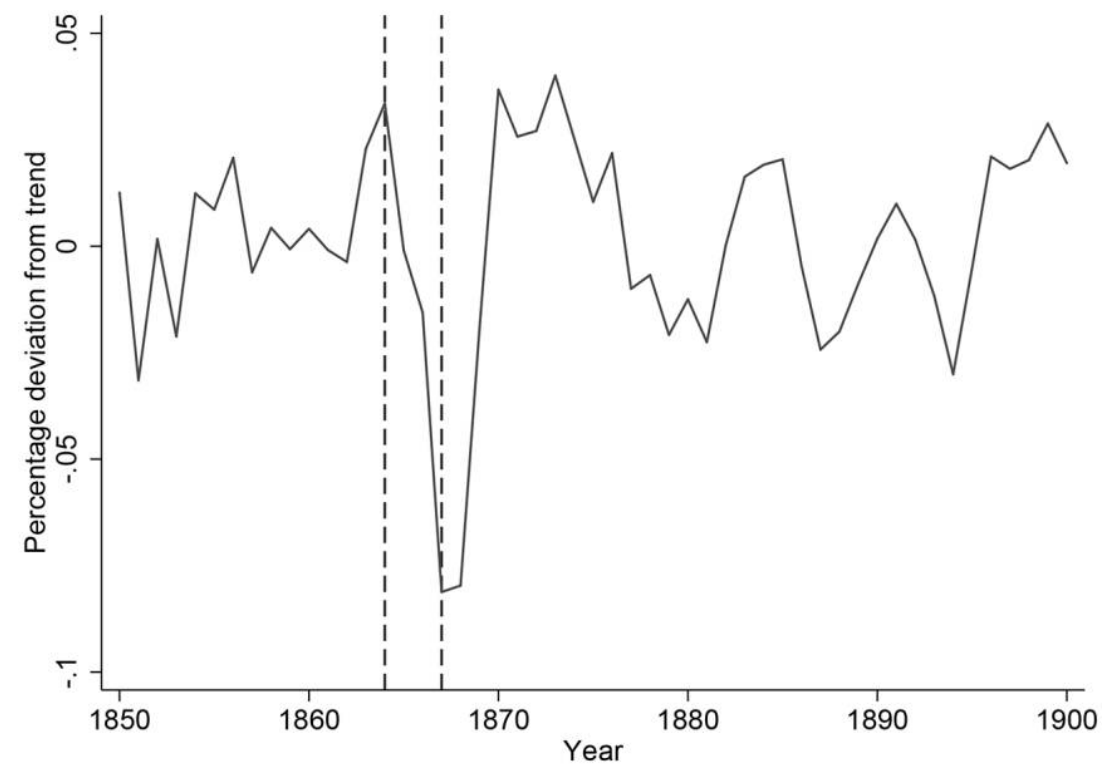

FIG. 3.-Detrended real GDP per capita, 1850-1900. This figure displays the cyclical component of Swedish real GDP per capita between 1850 and 1900, using a HodrickPrescott filter with smoothing parameter set to 100. The area between the dotted lines indicates the years used when defining our measure of frost shocks, 1864-67. Source: Edvinsson (2013).

cent of the population lived in rural areas and only 11 percent of the labor force worked in manufacturing (Edvinsson 2005). Cities and towns were indirectly affected, however, as the supply of food and the demand for goods and services dropped (Beijbom 1995). ${ }^{15}$ Figure 3 displays detrended Swedish real GDP per capita for 1850-1900, which has a visible trough in the late 1860 s. $^{16}$

Later emigration waves occurred during the 1880 s and at the turn of the century, as seen in figure 2. This pattern was common throughout Europe and has been linked to the booms in the United States coinciding with busts in Europe and vice versa (Hatton 1995). For Sweden, differences in growth rates between the United States and Sweden have been shown to predict aggregate emigration flows between 1870 and 1910 (Bohlin and Eurenius 2010). Social networks were also crucial drivers of

${ }^{15}$ In our data set, 28.3 percent of the emigrants during 1867-1920 are from urban areas.

${ }^{16}$ Several factors are likely to have interacted with the poor harvests in sparking the first wave of mass emigration to the United States. The introduction of steamship technology led to a shift away from sailing ships in the late 1860s, and the cost of migration fell considerably. The US Homestead Act of 1862, which offered free land to immigrants, together with the end of the US Civil War in 1865 are also considered to have contributed to the large number of emigrants observed (Barton 1994). 
emigration in the later waves. Firsthand accounts of Swedes in the United States reveal that many would not have emigrated were it not for having family members overseas (Sundbärg 1913). Having emigrants in one's network lowered the uncertainty and cost associated with traveling to the United States and finding an occupation once there (Runblom and Norman 1976). Postal communication was well developed, and emigrants frequently sent home prepaid tickets for family members to join them in America. ${ }^{17}$ Prepaid tickets accounted for up to half of all travelers. ${ }^{18}$

Combining migration and census data for 1880-1910, we can compare aggregate distributions of age, gender, and occupation. In terms of gender and occupation, emigrants are roughly similar to the population, although the female share is slightly lower among emigrants, with about 45 percent of migrants being women. As in the population, most migrants were either service workers or workers within the agricultural or industrial sector. Migrants were younger as compared to the population, with the bulk of emigrants being between 18 and 30 years old.

The mass emigration of Swedes did not go unnoticed among the elites. Policies to reduce emigration were proposed throughout the period and applied a mix of carrot and stick strategies: proposals to restrict emigration were common, as were calls for improving living standards so as to induce citizens to stay. In 1869, at the height of the first wave, several motions advocating emigration restrictions were raised in parliament by its members from high-emigration counties. Even at this very early stage, the awareness of and the concern about emigration were high (Kälvemark 1972). The central government surveyed governors in 1882 about their counties' experiences with emigration. A majority of governors agreed that emigration was a net bad for the country (Kälvemark 1972). When asked for policy proposals to reduce emigration, governors suggested measures both to make emigration more difficult and to improve the conditions in Sweden, for example, by facilitating the procurement of small land plots by landless farmers. ${ }^{19}$ However, emigration remained unrestricted throughout the mass migration period.

The return of high emigration rates in Sweden in the early twentieth century brought the strongest political reactions yet. Landowners and agrarian interest groups worried about labor scarcity and identified em-

\footnotetext{
${ }_{17}$ Data from Denmark, which had a much smaller number of emigrants than Sweden, have shown that up to 1.8 million letters were sent yearly to Denmark from the United States (Beijbom 1995).

${ }^{18}$ Studies of the archives of the Larsson Brothers emigration agency in Gothenburg have shown that around half of their clients traveled using prepaid tickets (Runblom and Norman 1976). Beijbom (1995) also reports that half of the Swedish emigrants traveled on prepaid tickets at the beginning of the 1880 s and around 40 percent by the end of that decade. Prepaid tickets also accounted for 40 percent of the Norwegian travelers (Hvidt 1975).

${ }^{19}$ Governors also identify family ties to emigrants as a chief determinant of emigration.
} 
igration as the main culprit. ${ }^{20}$ Others were concerned about the emigration of young men who would otherwise perform military service (Kälvemark 1972). These concerns ultimately led to the appointment of a large public commission, assigned the task of finding measures to end the mass emigration. When its 21-volume report was published in 1913, it recommended political reforms to improve the conditions of ordinary citizens to induce them to stay, rather than suggesting emigration restrictions (Sundbärg 1913). The large-scale emigration of Swedes ended in the 1920 s, likely because of a combination of US immigration quotas and the Great Depression.

\section{B. The Labor Movement and Emigration}

The Social Democratic Party was a dominant actor in Swedish politics during the twentieth century and long garnered a near majority of votes in national elections. Founded in 1889, it entered government for the first time in 1917 and remained in government for most of the twentieth century. The Social Democrats were closely linked to the Swedish Trade Union Confederation (LO), founded in 1898 as a central organization for the many smaller unions that existed at the time (Westerståhl 1945). Until then, the Social Democratic Party had in fact worked as the official central organization. Both organizations championed the right to organize, the 8-hour workday, and universal suffrage (Lundkvist 1977). ${ }^{21}$

The labor movement was regularly in conflict with employers and was known to use emigration as a tool to further its interests. In Stockholm, labor unions held English courses and helped colleagues emigrate. The Social Democrats' main newspaper updated readers about prospects in the US labor market (Tedebrand 1983). After the general strike in 1909, which was considered to be a defeat for the labor movement, a socialist newspaper called on workers to emigrate (Beijbom 1995). Many expatriate labor activists continued their work overseas, founding labor organizations in the United States (Nordahl 1994; Bengston and Brook 1999).

Emigration may have been useful to encourage membership in the labor movement because of the high risks involved in labor activism. Workers could be fired, evicted, or blacklisted for being union members. Un-

\footnotetext{
${ }^{20}$ Noting that landowners were less likely to emigrate, the state was encouraged to sell smaller plots of land and provide a transfer to enable poor farmers to acquire land. In a parliamentary debate in 1904, the central point of contention was if the subsidy should be so large that it allowed a farmer to be self-sufficient or should it be smaller, so that "owners would invariably need to seek employment with others in order to earn a living" (Kälvemark 1972, 129).

${ }^{21}$ The 8-hour workday and universal suffrage were adopted in 1919 by a Liberal-Social Democratic coalition government. In 1938, LO became a key player in the Swedish Labor Market model, representing employees in collective bargaining over wages and benefits without intervention of the national government.
} 
til 1885, an antiloitering law made striking illegal and punishable by forced labor (Westerståhl 1945).

A case study of the town of Ljusne elucidates the conflicted interactions between labor, elites, and emigration. In 1906, more than 100 workers emigrated from Ljusne, following a clash between the local Social Democratic club and the main employer, who owned all buildings in town and disallowed political and union organizing among workers. After the Social Democrats sent an incendiary telegram to the Swedish king, leading figures were fired while others were intimidated via the local police to stop their activities or be evicted. Rather than complying, many opted to emigrate. The option of emigrating was facilitated by the town's history of US migration: it had experienced a large participation in the emigration waves of the 1860s and 1880s. The news of Ljusne's "mass emigration" became widely spread in national media at the time and severely hurt the reputation of the owner and first chamber parliamentarian Count Walther von Hallwyl. When the plant shut down in 1907, the company announced that it would be paying pensions to older workers in gratitude for their service (Rondahl 1985).

\section{Data}

\section{A. Emigration Data}

We compile local emigration histories using two distinct, individual-level data sets encompassing the universe of registered emigrants during the Age of Mass Migration. The final data set contains 1.1 million emigrants from 1867 to 1920 . To our knowledge, this is the first study to make use of any of these two data sources for disaggregated statistical analysis. They are described in detail below.

The State Church in Sweden was historically tasked with tracking demographic statistics in its parishes. Births, deaths, marriages, and migration information were recorded year by year at the individual level and stored in parish records. These were later incorporated by the central statistical agency. We obtain emigration data from these parish records that were digitized by family researchers and through various municipal and county efforts. ${ }^{22}$ Individual migrants are matched to an origin municipality and year using information on the date of exit and home parish available in the data set.

The second source of individual-level emigration data is the archived passenger lists kept by shipping companies. Starting in 1869, at the peak of the first emigration wave, ships with foreign destinations were required

\footnotetext{
${ }^{22}$ The data are obtained from the Swedish Migration Center in Karlstad, Sweden.
} 
by law to compile lists of all their passengers (Clemensson 1996). The lists were controlled for authenticity by the police, who checked off travelers as they boarded their ships. The passenger manifests were later stored in various city archives and were digitized by the Gothenburg Provincial Archives. ${ }^{23}$ The same matching procedure as the parish-level data is used to match emigrants to origin municipalities. However, as passengers report their "home town" rather than exact parish or municipality of origin, the resulting match rate is lower compared to the parish data set.

Since the two data sets are independently collected and record emigrants at different points in time, it is possible to ascertain their accuracy by cross-checking the two sources. Online appendix section A.1 shows that there is a high degree of within-year correlation between the data sources. This indicates a high reliability of the emigration numbers. It also indicates that there is no important lag between leaving the home parish and boarding a ship to the United States, consistent with earlier research (Runblom and Norman 1976).

In the remainder of the paper, we use a single emigration variable defined as the maximum of either the church book or passenger list data each year. The primary concern is in undercounting emigrants. Undocumented emigration may be lacking from parish data, while the passenger list data are imperfectly matched to parishes. As a result, using the maximum value each year yields our best estimate of emigration. ${ }^{24}$

\section{B. Election and Labor Movement Data}

We use municipal-level voting data for all national elections between 1911 and $1921 .^{25}$ The data set includes the number of eligible voters and votes cast as well as the distribution of votes across political parties. ${ }^{26}$ Precinct-level data from municipal and national elections from 1998 to 2014 are taken from the Swedish Election Authority and are geographically matched to 1865 municipality borders.

${ }^{23}$ The data set is obtained from the 2006 Göteborgsemigranten Emigranten Populär Database, available in Gothenburg by Per Clemensson.

${ }^{24}$ After 1895, all data are necessarily from passenger lists since church books have not been digitized after that year. Before 1895, the parish data report strictly more emigrants 55 percent of the time, while the passenger data indicate strictly greater numbers 25 percent of the time. In 23 percent of cases, the data sets are equal.

${ }_{25}$ The database Svenska valdata $1911-1944$ is provided through the Swedish National Data Service.

${ }_{26}$ The data begin in 1911 as it was the first year when party denominations were formally required of all members of parliament. Before then, the parliament consisted of a mix of partisans and independents, and partisanship was not systematically recorded. In the absence of roll call data from the period, this makes it hard to determine the political identification of members of parliament before 1911. Roll call data from the parliament were not recorded until 1927. 
Local organization membership for 1881-1945 comes from the Social Movement Archive. ${ }^{27}$ The Social Movement Archive lists the number of members by municipality as of December 31 each year for the following organizations: free churches, temperance lodges, labor unions, and the Social Democratic Party. We group labor unions and the Social Democratic Party into one variable that we label labor movement membership. These organizations were tightly connected and largely worked toward the same political goals, as described in Section II, making labor movement membership a summary indicator for citizens' demand for political change.

Participation numbers for the 1909 general strike, divided by union and non-union members, are digitized from the original government report following the strike (Kommerskollegii 1910).

\section{Weather Data}

Daily temperature data are obtained from the historical records of the Swedish Meteorological and Hydrological Institute. We complement this with daily data for Norwegian weather stations near the Swedish border, provided by the Norwegian Meteorological Institute. The Swedish data contain temperature readings three times per day: 6:00 a.m., 12:00 p.m., and 8:00 p.m. In addition, most observations have daily minimum and maximum temperatures. The Norwegian data contain daily average temperatures only. Appendix section A.2 describes how daily minimum temperatures are predicted from existing data in cases in which the minimum temperature is not available.

In total, the data contain 32 unique temperature stations between 1864 and 1867, with a median distance from municipality centroids to the nearest station of 36 kilometers. ${ }^{28}$ The relatively small number of stations could be a problem for our ability to find enough variation in weather conditions to precisely predict emigration. However, temperature is known to be evenly distributed over large areas, especially in the northern hemisphere. Rain is, by comparison, more idiosyncratic (Dell, Jones, and Olken 2014). Climatologists have also established that temperature deviations from long-run means are more similar over large distances as compared to levels (Hansen and Lebedeff 1987). Intuitively, the reason for this is that even if two neighboring locations have different temperature levels, for example, because of differences in altitude, they are likely to experience similar deviations from their long-run means within a given window of time due to common weather shocks. As our identification strat-

\footnotetext{
${ }^{27}$ The data set Folkrörelsearkivet $1881-1950$ is provided by the Swedish National Data Service.

${ }^{28}$ The mean distance is 39 kilometers.
} 
egy relies on estimating shocks to weather, we are precisely interested in using deviations, allowing us to exploit this feature of the data. Section IV describes how we define frost shocks in detail.

\section{Additional Data}

In the final data set, all variables are aggregated to the municipality level using 1865 boundaries. Georeferenced data on administrative borders in 1865 are taken from the National Archives of Sweden. Population data for 1865 are taken from Palm (2000) and the National Archives of Sweden. Soil suitability data for barley, oats, wheat, livestock, and forestry are from the Food and Agriculture Organization Global Agro-Ecological Zones database. County-level harvest grades for 1860-80 are from Hellstenius (1871) and Statistics Sweden. The harvest grades are assessments made by local agricultural societies and measure the overall yield for the crops cultivated in each county. Grades are given on an ordinal scale from 0 to 9 , with higher values indicating higher yields.

Municipal-level welfare expenditures and type of political institutions (direct or representative democracy) are taken from Hinnerich and Pettersson-Lidbom (2014). Mortality data for infants, children, and mothers, averaged over the 1850-59 period, are from the Demographic Data Base, Centre for Demographic and Aging Research, Umeå University. Complete decennial censuses for 1880-1920 were obtained from the National Archives of Sweden and the North Atlantic Population Project. The census gives population-wide data on demographic variables including gender, civil status, family structure, and occupation. Summary statistics are presented in table 1 .

\section{Empirical Framework}

Our goal is to estimate the effect of emigration over the course of the Age of Mass Migration on long-run political outcomes in origin municipalities. The cross-sectional equation of interest is

$$
y_{m c t}=\beta \text { Emigration }_{m c t}+\phi_{c}+\mathbf{X}_{m c}^{\prime} \beta_{X}+\eta_{m c t},
$$

where $y_{m c t}$ is a political outcome in municipality $m$, county $c$, and year $t$; Emigration $_{m c t}$ is the log of cumulated emigration from 1867 to year $t$; $\phi_{c}$ is a fixed effect for the 24 counties; and $\mathbf{X}_{m c}$ is a vector of municipality characteristics determined before the start of mass emigration. The specification focuses on the stock of emigrants as a determinant of political outcomes, capturing the extent of overseas social networks present in a municipality and, hence, the ease of future migration for current citizens. We estimate (1) by ordinary least squares (OLS) as a baseline, al- 
TABLE 1

Summary STATISTICS

\begin{tabular}{|c|c|c|c|c|c|}
\hline & Mean & $\begin{array}{l}\text { Standard } \\
\text { Deviation }\end{array}$ & $\mathrm{P} 10$ & $\mathrm{P} 50$ & P90 \\
\hline Frost shocks $1864-67$ & 4.577 & 2.765 & 2.000 & 3.000 & 9.000 \\
\hline Proximity to emigration port & -5.025 & .989 & -6.085 & -5.135 & -3.739 \\
\hline Emigration $1867-1920$ & 5.392 & 1.272 & 3.664 & 5.485 & 6.924 \\
\hline Emigration 1867-79 & 3.591 & 1.483 & 1.609 & 3.714 & 5.394 \\
\hline Emigration 1880-1920 & 5.173 & 1.260 & 3.526 & 5.247 & 6.683 \\
\hline Labor organization rate $1900-1920$ & .012 & .039 & .000 & .001 & .031 \\
\hline Strike participants per capita 1909 & .011 & .041 & .000 & .000 & .027 \\
\hline Left vote share $1911-21$ & .247 & .188 & .030 & .210 & .519 \\
\hline Turnout 1911-21 & .603 & .099 & .476 & .606 & .725 \\
\hline Welfare expenditures per capita 1918 & 2.414 & 2.116 & .841 & 2.064 & 4.183 \\
\hline Welfare expenditures per capita 1919 & 2.756 & 1.941 & .972 & 2.384 & 4.794 \\
\hline Direct democracy 1919 & .633 & .482 & .000 & 1.000 & 1.000 \\
\hline Population 1865 & 7.079 & .782 & 6.094 & 7.047 & 8.078 \\
\hline Urban & .048 & .214 & .000 & .000 & .000 \\
\hline Area & 8.634 & 1.264 & 7.209 & 8.483 & 10.147 \\
\hline Arable land share & .702 & .220 & .500 & .667 & 1.000 \\
\hline Proximity to trade port & -4.382 & .926 & -5.294 & -4.516 & -3.209 \\
\hline Proximity to town & -2.772 & 1.215 & -3.833 & -2.917 & -1.911 \\
\hline Proximity to Stockholm & -5.534 & .725 & -6.193 & -5.746 & -4.452 \\
\hline Proximity to railway & -3.151 & 1.429 & -4.907 & -3.263 & -1.317 \\
\hline Proximity to weather station & -3.482 & .681 & -4.174 & -3.594 & -2.620 \\
\hline Latitude & 58.337 & 2.023 & 55.881 & 58.171 & 60.418 \\
\hline Longitude & 14.824 & 2.064 & 12.594 & 14.217 & 17.859 \\
\hline Barley & .239 & .426 & .000 & .000 & 1.000 \\
\hline Oat & .136 & .343 & .000 & .000 & 1.000 \\
\hline Wheat & .177 & .382 & .000 & .000 & 1.000 \\
\hline Livestock & .224 & .417 & .000 & .000 & 1.000 \\
\hline Forest & .180 & .384 & .000 & .000 & 1.000 \\
\hline
\end{tabular}

NoTE.-This table displays the mean, standard deviation, and median as well as the 10th and 90 th percentiles of the main variables. Emigration, population, area, and proximity variables are in logs. Proximity is defined as minus the log of distance. Frost shocks 1864-67 is the sum of growing season frost shocks during 1864-67 as defined in Sec. IV. Labor organization rate $1900-1920$ is the number of members in labor unions and the Social Democratic Party, expressed in per capita terms and averaged between 1900 and 1920. Strike participants per capita 1909 is the number of participants in the 1909 general strike divided by municipal population. Urban is an indicator variable equal to one for urban municipalities. Direct democracy 1919 is an indicator variable equal to one if a municipality had direct local democracy in 1919. Barley, oat, wheat, livestock, and forest are indicator variables capturing high soil suitability for the related agricultural produce.

ways including the log of population in 1865 in $\mathbf{X}_{m c}$ in order to scale the level of emigrants to the initial municipality size.

For several reasons, long-run emigration histories can be expected to correlate with important characteristics of the origin municipality, either observable or unobservable, that can have a direct impact on the outcomes of interest. A strong concern in estimating (1) by OLS is hence that it may yield biased estimates of the effects of emigration. In particular, the risk of picking up reverse causation is high. Locations with fa- 
vorable initial institutions may induce more emigration because of better access to information or higher incomes. In contrast, places with more repressive leaders might actively inhibit emigration, thus leading to a positive bias in the OLS estimate of $\beta$. In the abstract, the reverse situation is, however, equally likely: fewer people may want to leave locations with good institutions and bad institutions could act as a push factor for emigrating. Without the ability to quantify the relative importance of these effects, OLS estimates yield limited information about the causal effect of emigration on local politics.

To overcome the issues related to omitted variables and to consistently estimate parameters, we propose an identification strategy exploiting migration-related push factors prior to the first wave of mass emigration: the interaction between growing season frost shocks in 1864-67 and the proximity from a municipality to the nearest of the two main emigration ports. Owing to chain migration, these early push factors should predict cross-sectional variation in total emigration over extended periods of time. The remainder of the section describes how we construct frost shocks and proximity to emigration port and presents the instrumental variables (IV) strategy in more detail.

\section{A. Frost Shocks}

The empirical economics literature often uses rainfall as a source of exogenous variation in income for developing countries, motivated by the idea that rainfall has a direct effect on crop yields. Less attention has been given to the importance of temperature variation. However, low temperatures and frost in particular are closely linked to agricultural outcomes in nontropical climates (Snyder and Melo-Abreu 2005). Frost has severe effects on crop growth and the likelihood of plant death. In the United States, more economic losses are caused by freezing of crops than by any other weather hazard (White and Haas 1975). One night of freezing temperatures can lead to a complete crop loss (Snyder and MeloAbreu 2005). As mentioned in Section II, the poor harvests in Sweden in the 1860s occurred during years with unusually cold temperatures in the growing season. Throughout Sweden, frost was observed as late as in June, in the middle of the growing season for most municipalities in our data. Estimating the incidence of frost is difficult, however, as it requires not only daily data but also estimates of the minimum temperature at a daily resolution.

We define monthly frost shocks following the approach of Harari and La Ferrara (2013), expressing shocks relative to the local long-run weather in that particular month. For each month $r$, year $t$, and weather station $s$, we calculate the deviation between the actual and the long-run average number of frost days in that month: 
OOO

$$
\text { deviation }(\text { Frost Days })_{s r t}=\text { Frost Days }_{s r t}-\overline{\text { Frost Days }}_{s r} \text {, }
$$

where a frost day is a day with a minimum temperature below $0^{\circ} \mathrm{C}$. A frost shock at the municipality level is then defined as a binary variable:

$$
\text { Shock }_{m s t} \equiv I\left[\text { deviation }(\text { Frost Days })_{s r t}>\mathrm{SD}\left(\text { Frost Days }_{m r}\right)\right],
$$

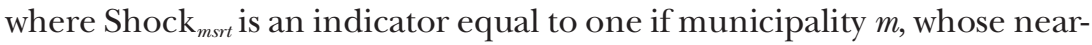
est station is $s$, experienced a positive frost shock in month $r$ of year $t .^{29}$ The municipality's long-term standard deviation of frost days in each month is denoted SD(Frost Days) ${ }_{m r}{ }^{30}$ Note that we compute the deviation from the long-term mean at the weather station level rather than the municipality level. This exploits the fact that weather variables are more precisely interpolated in deviations from long-term means than in levels, as discussed in Section III (Hansen and Lebedeff 1987). Finally, we sum the number of shocks over the growing season for each municipality over the 1864-67 period. We exploit shocks occurring only during this 4-year period as it was bookended by a particularly high incidence of cold temperatures, with shocks rarely occurring in other years of the decade. A growing season month is defined as a month with a long-term mean temperature above $3^{\circ} \mathrm{C}$, following guidelines of the Swedish Meteorological and Hydrological Institute.

Figure 4 displays the spatial distribution of growing season frost shocks during 1864-67, indicating considerable variation in shocks across Sweden. ${ }^{31}$ The frequency distribution of frost shocks during 1864-67 is displayed in figure 5 . As evidenced by the figure, this period saw a high incidence of cold temperatures in the growing season, with the median municipality experiencing three frost shocks.

\section{B. Proximity to Emigration Port}

To proxy for the within-country travel cost of emigration, we calculate the proximity to an emigration port, defined as minus the log distance

\footnotetext{
${ }^{29}$ Municipalities are matched with the nearest weather station available in each month. Enough variation is captured by the nearest station so that using more weather stations (e.g., the second- and third-nearest ones) does not contribute substantial additional information. In our data, the adjusted $R^{2}$ from regressing monthly frost days at weather station $s$ on frost in the nearest neighboring weather station is only slightly higher when we add the frost of the second-nearest weather station, as seen in online app. table A.2.

${ }^{30}$ As more weather stations are added over time, calculating the long-term standard deviation at the municipality level will use data from stations that are closer to the municipality. This introduces more precision in estimates compared to using only the stations that were available in the pre-emigration period.

31 Appendix sec. A.3 displays the underlying monthly variation in municipalities' frost days during six growing season months of 1864 and 1867.
} 


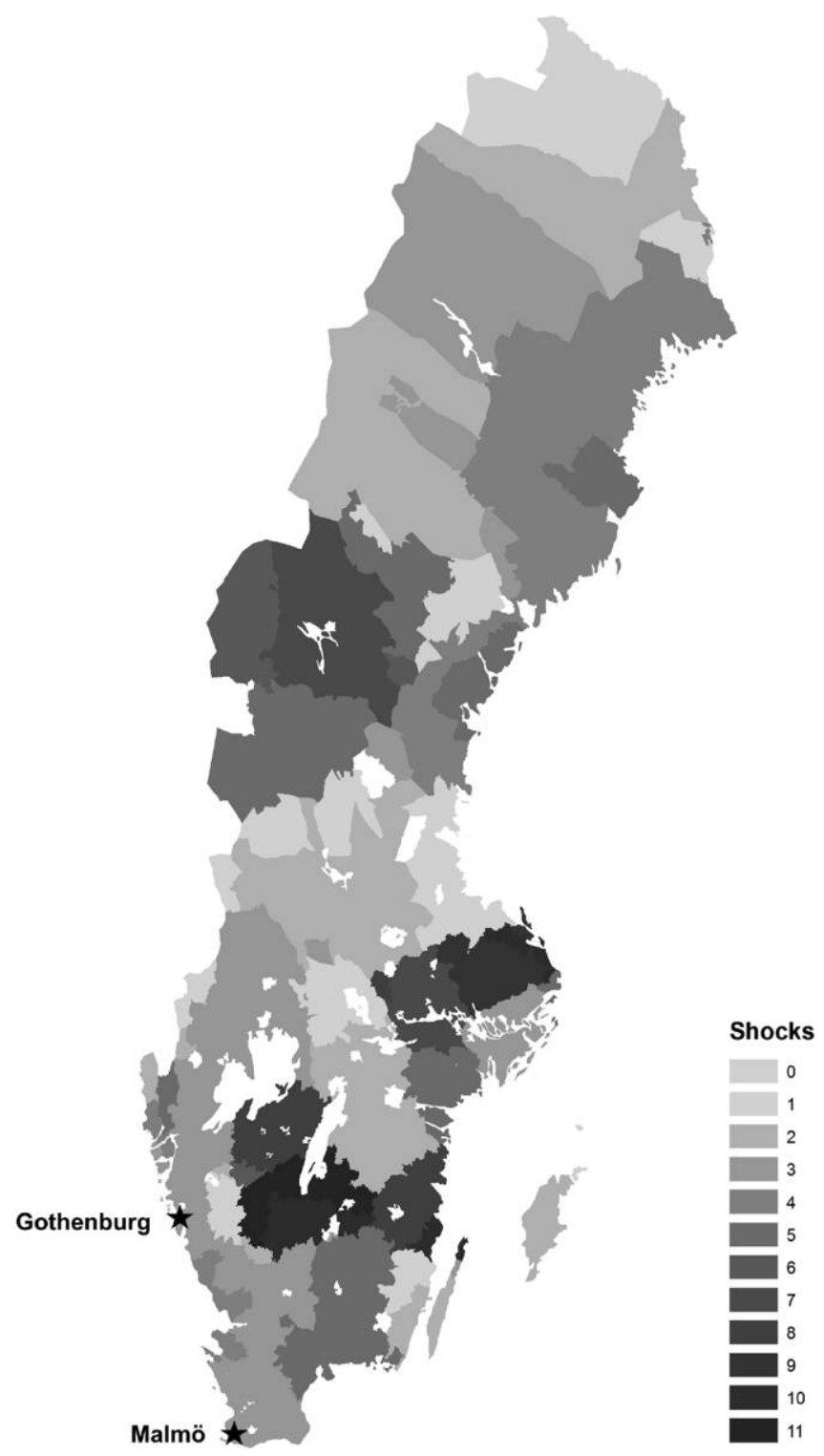

FIG. 4.- Spatial distribution of growing season frost shocks, 1864-67, used to define the instrumental variable. Darker areas indicate a higher number of shocks. Frost shocks are defined by month, relative to the local long-term mean and standard deviation of frost in that month. The two main emigration ports, Gothenburg and Malmö, are indicated by stars. 

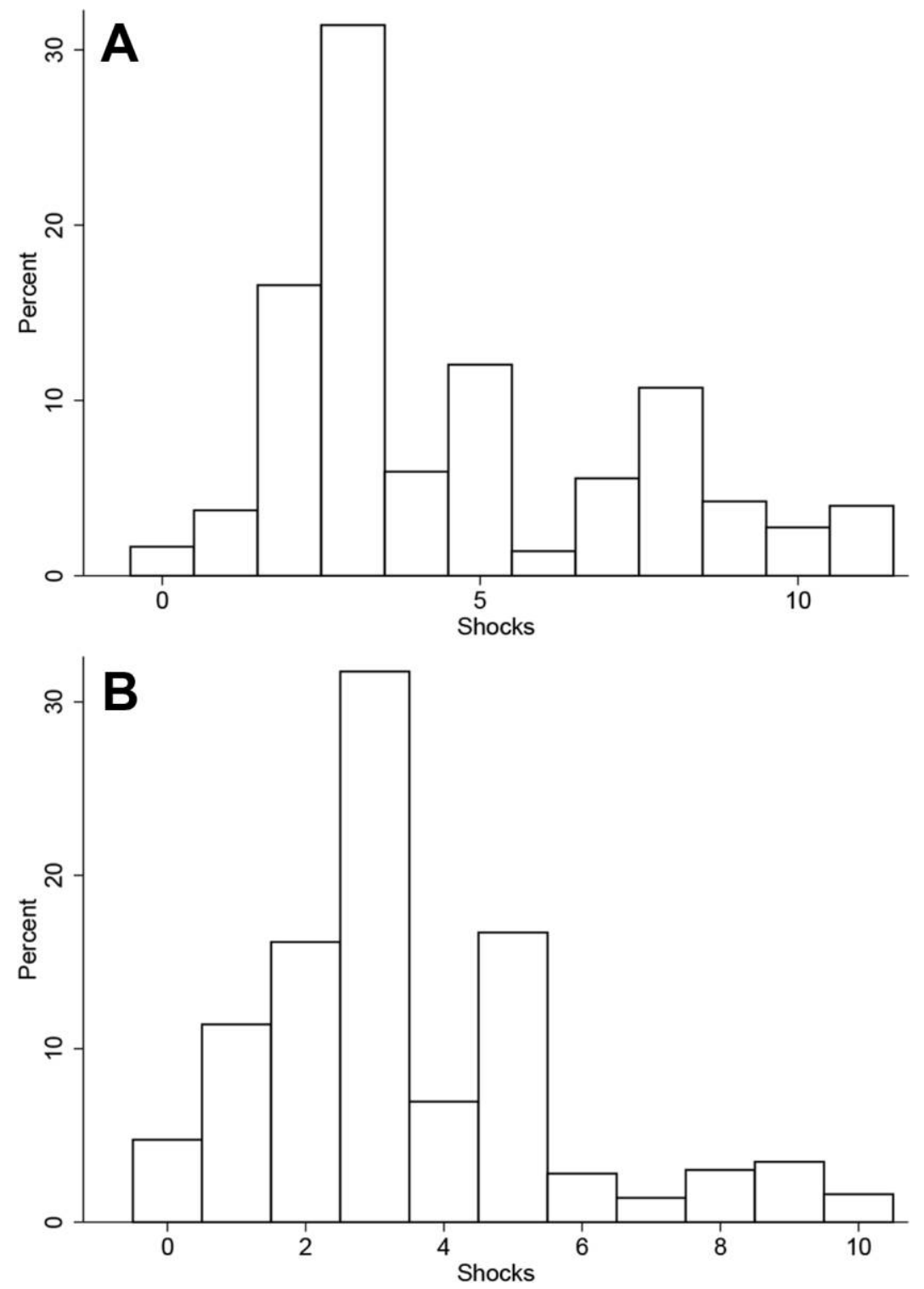

FIG. 5.-Frequency distribution of frost shocks, 1864-67, by growing season (panel A) and nongrowing season (panel B). Shocks are defined at a monthly resolution. For example, a value of 5 in panel A indicates that a municipality experienced five growing season months with unusually high frost incidence between 1864 and 1867. 
to either Gothenburg or Malmö, whichever is closest. ${ }^{32}$ The two cities were the main emigration ports during the Age of Mass Migration and the second- and fourth-largest cities in 1865, respectively. Likely because of economies of scale, the points of exit were very concentrated, and between them the cities handled more than 95 percent of all emigration before 1920. Their importance is confirmed by comparing yearly emigration shares across ports. ${ }^{33}$ Figure 6 displays the share of emigrants exiting through four ports over the period 1869-1920. Gothenburg was the biggest port by far throughout the period, with 79 percent of all traffic on average and about 82 percent during the first wave of emigration. Malmö was the second-largest emigration port, with 18 percent of the emigrants on average and 14 percent during the first wave. ${ }^{34}$

Stockholm, the capital and Sweden's largest city by far, averaged 2 percent of total emigrants. This low share is likely driven by supply and not by demand factors. ${ }^{35}$ While the Stockholm region sent a large number of emigrants, Stockholm was less suited as an emigration port because of its location on the eastern coast of Sweden. Similarly, Norrköping, the thirdlargest city and an important trade port, was minor in terms of emigration. In our data set, 75 percent of the municipalities have Gothenburg as their closest emigration port, while the rest are closer to Malmö. ${ }^{36}$

Emigration via Norwegian ports was an option for some northern municipalities but was rare until the late nineteenth century. Hence it is not of relevance for the period we use to define our instrument. ${ }^{37}$

\section{Identification Strategy}

In order to consistently estimate the effect of emigration on political outcomes, we instrument for emigration using the number of growing sea-

32 Distances are calculated using the great-circle haversine formula. Our results are robust to excluding lakes and waterways between municipalities and Gothenburg or Malmö; see app. table B.1. To specifying proximity in levels rather than logs, see table B.10. Figure 4 shows that the proximity to Gothenburg and Malmö is well approximated by a straight line for most locations in Sweden.

${ }^{33}$ Shares are computed using the passenger list data, which include emigrants' port of exit. Information on port of exit is not available in the church book data set.

${ }^{34}$ The data distinguish between emigrants from Malmö and Copenhagen. Owing to their geographical proximity and because most emigrants likely transited via Malmö before being registered in Copenhagen, we count the two exit ports as one unit.

${ }_{35}$ Table B.8 shows that results are robust to excluding Stockholm county from the analysis.

36 The most common travel route was by steamship from Gothenburg to Hull on the east coast of England and then from Liverpool on the west coast to New York City, with a train connection in between (Brattne and Akerman 1976). In terms of travel time, distance to an emigration port constituted a considerable share of total travel time to the United States. Travel by ship from Gothenburg to New York took around 10 days, while it took 14 hours by rail to reach Gothenburg from Stockholm in the late 1860s.

37 Appendix sec. B.2 provides more details and shows that results are robust to including Norwegian ports in our proximity measure. 


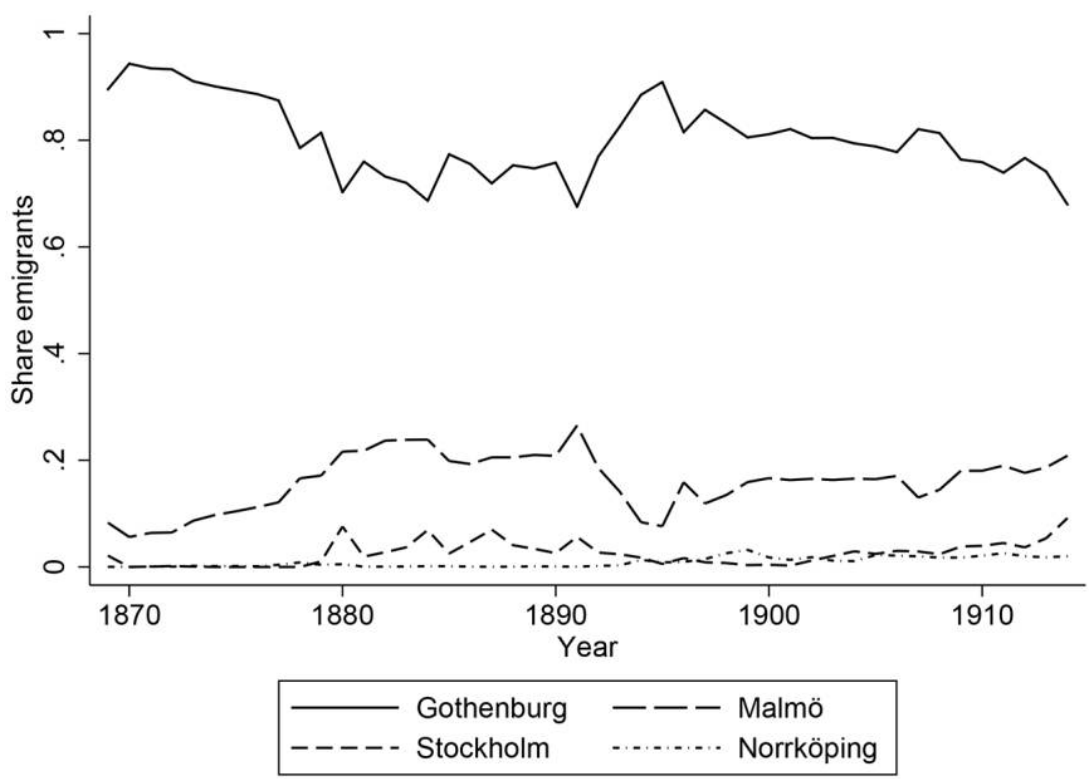

FIG. 6.-Main emigration ports. Share of total emigrants per year, 1869-1914, by port of emigration. Source: passenger list data set.

son frost shocks in 1864-67 interacted with the proximity to the nearest emigration port. The first-stage and second-stage equations are

$$
\begin{aligned}
\text { Emigration }_{m c t}= & \gamma_{S P}(\text { Shocks } \times \text { Port })_{m c}+\gamma_{S} \text { Shocks }_{m c}+\gamma_{P} \text { Port }_{m c} \\
& +\theta_{c}+\mathbf{X}_{m c}^{\prime} \gamma_{X}+v_{m c t}, \\
y_{m c t}= & \beta \overline{\text { Emigration }_{m c t}}+\beta_{S} \text { Shocks }_{m c}+\beta_{P} \text { Port }_{m c} \\
& +\phi_{c}+\mathbf{X}_{m c}^{\prime} \beta_{X}+\varepsilon_{m c t},
\end{aligned}
$$

where Shocks ${ }_{m c}$ is the number of frost shocks in 1864-67 in municipality $m$ of county $c$, Port $m c$ is the proximity to the nearest emigration port, $(\text { Shocks } \times \text { Port })_{m c}$ is the single excluded instrument, and Emigration Ect is predicted emigration from the first-stage equation (3). In a balance test, discussed below, we show that the instrument does not systematically correlate with pre-emigration municipal characteristics included in $\mathbf{X}_{m c}$. By including county fixed effects and using proximity in logarithms (rather than levels), the identifying variation does not disproportionately rely on northern counties where the distance to ports and distance between municipalities are larger. Section IX documents that our results are not driven by the locations that are farthest away from ports. 
The intuition behind the identification strategy is twofold. First, the marginal effect of frost shocks on emigration should be larger for municipalities that are close to emigration ports. In other words, when there is an incentive to move (due to frost shocks), we should observe more emigration where the fixed cost of migration is also lower. ${ }^{38}$ Second, because of path dependence in migration, the instrument should predict not only first-wave migration but migration over longer periods of time.

The key identifying assumption is that only emigration is directly affected by the interaction between frost shocks and port proximity, conditional on our set of controls. Formally, the exclusion restriction is

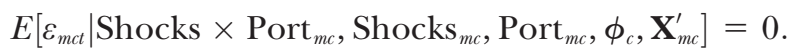

An important feature of our identification strategy is that we control for the direct effects of frost shocks and port proximity in (4). ${ }^{39}$ This is beneficial because studies that use weather shocks as instruments are typically marred by the problem that weather may simultaneously affect many variables (Giuliano and Spilimbergo 2014; Sarsons 2015). In our setting, locations that experience more severe frost shocks may obtain weaker government finances, worse public health, or other features that can affect our outcomes without going through emigration. Similarly, port proximity may be related to other confounding factors. ${ }^{40}$ Frost shocks and port proximity themselves are therefore not valid instruments, as the exclusion restriction would likely be violated. ${ }^{41}$

While we can control for the direct effects of frost shocks and port proximity, a concern for the credibility of our exclusion restriction is that frost shocks may cause economic effects of different intensity depending on proximity to emigration ports. Locations near Gothenburg and Malmö, for example, may have better market access, which could imply a differential sensitivity to frost shocks due to less volatile prices, better insurance opportunities, or a lower reliance on agriculture. If so, the instrument could affect our outcomes through channels related to the intensity of

\footnotetext{
${ }^{38}$ Frost shocks and port proximity are hence hypothesized to be complements for emigration. The direction of this relationship is an empirical matter, however, as the two variables could also be substitutes. For identification purposes, what matters is that the relationship fulfills the monotonicity assumption, i.e., that the effect is the same for all observations. Figure 8 below displays evidence consistent with this assumption.

${ }^{39}$ In table B.11 we also estimate models that control for more flexible functional forms of these variables.

40 Table A.3 provides pairwise correlations of emigration port proximity with a number of pre-emigration characteristics of municipalities.

${ }^{41}$ There may be interactions between frost shocks and other municipal characteristics that also predict emigration and could be candidates for an instrument. However, such interactions are unlikely to cause only emigration to change. For example, frost shocks interacted with local GDP may predict emigration but may also pick up variation in the economic impact of the frost shocks. Such an interaction would not predict variation only in emigration rates and hence violate the exclusion restriction.
} 
economic shocks rather than through emigration, violating the exclusion restriction.

To account for the confounding variation mentioned above, we include specifications that control for the interaction effect of frost shocks and two direct measures of proximity to economic hubs: a municipality's proximity to the nearest of the 10 largest trade ports as well as to the nearest town. These controls are denoted as shocks $\times$ market access in our tables. We use the term market access as a catchall term for factors that may mediate the economic effect of frost shocks and that correlate with proximity to economic hubs. In Section IX we also show specifications in which market access is measured using smaller subsets of only the larger trade ports and towns, to check if results are robust to different definitions of market access. As a separate test, we also include interactions between frost shocks and pre-emigration measures of agricultural activity. These specifications test for the possibility that local economic structure may covary with port proximity and cause different responses to frost shocks. Finally, Section IX also presents results from testing the robustness of our results to the method of Conley, Hansen, and Rossi (2012), which yields unbiased estimates under the assumption of some specified degree of violation of the exclusion restriction.

The late nineteenth century brought several international trade shocks that led to important changes in, for example, the dairy and lumber sectors (O'Rourke 1997). If our instrument is related to the agricultural or broader economic structure of municipalities, there is a risk that such later trade shocks are picked up by it, which would violate the exclusion restriction. ${ }^{42}$ However, table 2 displays that there is no significant relationship between the instrument and several measures of soil suitability for the goods that were subject to trade shocks. Hence, later changes in trade patterns should not be a concern for our estimates.

\section{Balance Test}

Our identification strategy relies on our instrument being exogenous with respect to municipality characteristics determined before mass migration. We test this by performing balance tests of the instrument on a number of observable variables at the municipality level. Table 2 displays the outcome of these tests. The instrument is uncorrelated with all variables but one, log population in 1865. By random chance, we should expect some variable to be correlated with the instrument. Yet it is reassuring that the correlation predicts that high-emigration municipalities have lower baseline population levels, while it is expected that larger mu-

${ }^{42}$ For example, Schultz (1985) finds that the relative price increase of dairy vs. grain products increased female labor supply and sparked the Swedish fertility transition. 
TABLE 2

Balance Tests: OLS Regressions

\begin{tabular}{lcc}
\hline \hline & \multicolumn{2}{c}{ DEPENDENT VARIABLE } \\
\cline { 2 - 3 } & \multicolumn{1}{c}{$(1)$} & $(2)$ \\
\hline Population 1865 & $-.0476^{* *}$ & $(.0175)$ \\
Urban & -.0038 & $(.0024)$ \\
Area & -.0124 & $(.0261)$ \\
Arable land share & .0031 & $(.0046)$ \\
Proximity to trade port & .0122 & $(.0209)$ \\
Proximity to town & -.0416 & $(.0268)$ \\
Proximity to Stockholm & .0205 & $(.0244)$ \\
Proximity to railway & .0164 & $(.0396)$ \\
Proximity to weather station & .0023 & $(.0211)$ \\
Latitude & -.0267 & $(.0227)$ \\
Longitude & -.0183 & $(.0204)$ \\
Barley & .0081 & $(.0088)$ \\
Oat & -.0022 & $(.0058)$ \\
Wheat & .0038 & $(.0033)$ \\
Livestock & .0061 & $(.0094)$ \\
Forest & -.0121 & $(.0080)$ \\
Infant mortality & -1.3808 & $(1.0198)$ \\
Child mortality & -.7629 & $(1.0723)$ \\
Maternal mortality & -.0810 & $(.5028)$ \\
Population growth 1810-65 & -.0061 & $(.0065)$ \\
\hline
\end{tabular}

Note.-This table displays the correlation between the instrument and a set of variables determined before mass emigration. Each row represents a separate regression of the dependent variable on growing season frost shocks $1864-67$, proximity to the nearest emigration port, and their interaction, which is our instrument. All regressions include county fixed effects. Col. 1 displays the coefficient related to the instrument, while col. 2 displays standard errors. Proximity variables are defined as minus the $\log$ of the distance. Population, area, and proximity variables are in logs. Urban is an indicator variable equal to one for urban municipalities. Barley, oat, wheat, livestock, and forest are indicator variables capturing high soil suitability for the related agricultural produce. Mortality variables are expressed per 1,000 births and are averaged between 1850 and 1859. The number of observations is 2,359 , except for the final four variables, which have $1,785,1,779,1,269$, and 2,308 observations, respectively. Standard errors (in parentheses) are clustered at the weather station level.

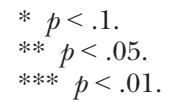

nicipalities are more politically organized. ${ }^{43}$ Nevertheless, the 1865 population is included in all regressions as a control. We include the following additional control variables: log area, latitude, longitude, the share of arable land, and an urban indicator, as well as indicators for high soil

43 Table A.4 documents that the population in 1865 is positively correlated with political outcomes such as labor organization rates, strike rates, and welfare spending, while it is unrelated to support for left-wing parties. It is negatively correlated with turnout, however. 
suitability for the production of barley, oats, wheat, dairy, and lumber. We also include the following proximity measures, all in logarithms: to the nearest weather station, to the nearest railway, to Stockholm, to the nearest town, and to the nearest of the 10 most important trade ports in $1890 .^{44}$

The three mortality variables, as well as population growth during 1810-65, at the bottom of table 2 , are not included as control variables in our regressions because of a lower number of observations. They provide relevant tests of the instrument, however, as they directly relate to municipal policy and well-being prior to mass emigration. ${ }^{45}$ The instrument is not correlated with population growth before emigration, nor with any measure of mortality, whether it is for infants, children, or mothers.

\section{Frost Shocks, Travel Cost, and Emigration}

\section{A. Frost and Agricultural Outcomes}

Before investigating the link between the instrument and emigration, we verify the effect of frost shocks on agriculture using a panel of county-level harvest grades from 1860 to 1880 . Column 1 of table A.5 shows that frost shocks in the growing season indeed cause worse harvests in the same year. A standard deviation increase in frost shocks causes a 10 percentage point higher probability of crop failure, an increase of about 0.25 standard deviations. The result holds controlling for county and year fixed effects, as well as county-specific linear trends. Column 2 provides evidence that the distinction between growing and nongrowing seasons is crucial, as shocks that occur in the nongrowing season have a near-zero and insignificant effect on harvests. If emigration was caused by poor agricultural yields, we should expect to find the same pattern when emigration is the dependent variable. Columns 3 and 4 reestimate the specifications in the first two columns using the full scale of harvest grades, with the results displaying the same pattern.

\section{B. First Stage}

We start by establishing the presence of path dependence in Swedish emigration. Figure 7 evaluates this pattern graphically. Panel A plots the spatial distribution of emigration rates during the first wave of emigration in 1867-79, while panel B displays emigration in the whole 18671920 period. Comparing the two maps indicates a substantial correlation in the propensity to emigrate over time. This is consistent with the fact

\footnotetext{
${ }^{44}$ As before, we define proximity as minus the log of distance.

${ }_{45}$ Maternal mortality was partially a function of local policies, as midwives were employed by parishes (Pettersson-Lidbom 2015).
} 

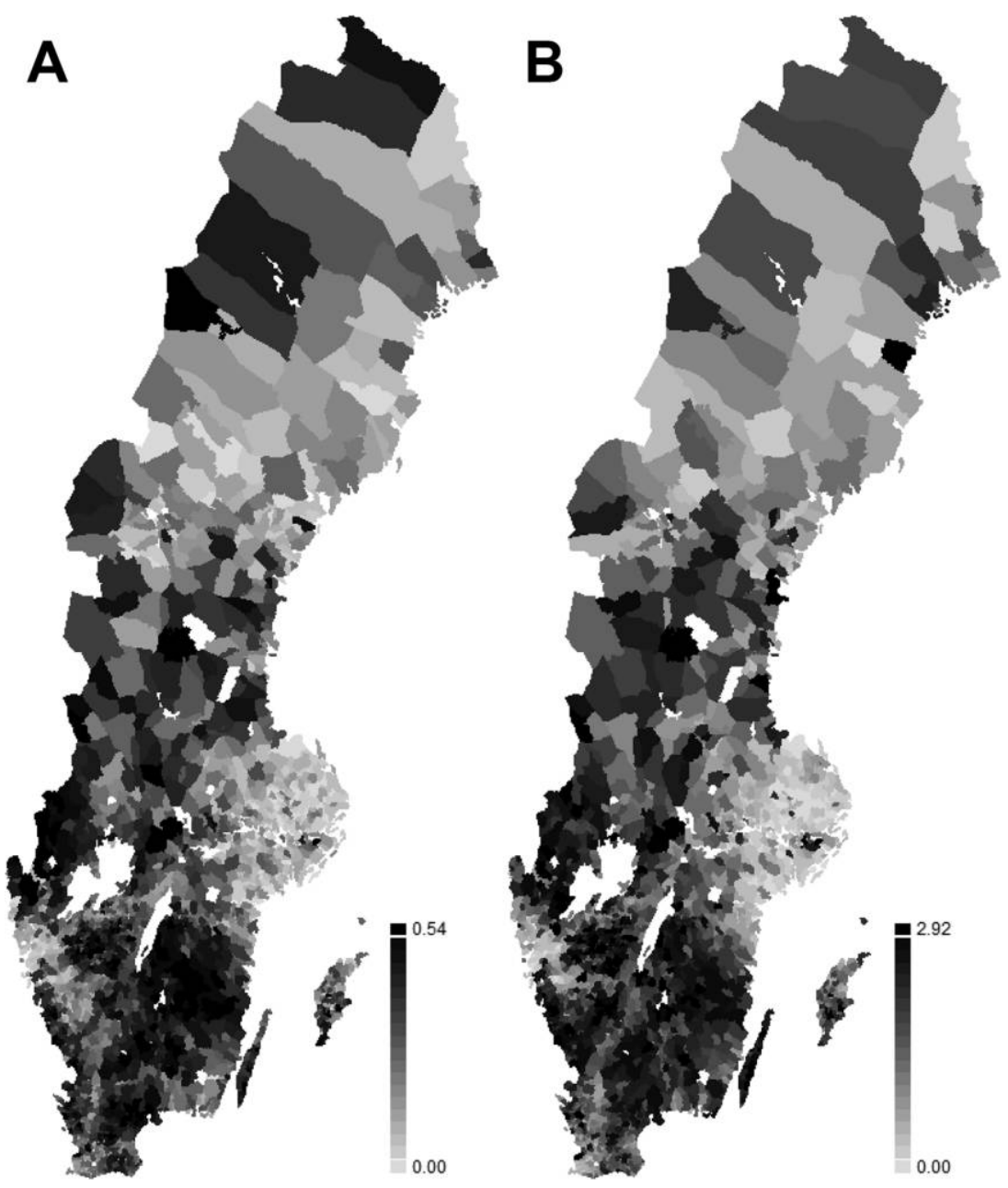

FIG. 7.- Spatial distribution of emigration during the first wave of emigration (panel A, 1867-79) and in total (panel B, 1867-1920). Each geographical unit represents one municipality. Emigration values are divided by the population in 1865 . Scales are relative to the distribution in the period in question.

that up to 50 percent of the emigrants traveled on prepaid tickets sent by network members in the United States (Runblom and Norman 1976; Beijbom 1995). Figure A.3 also displays the relationship between early and later emigration in a scatter plot, which displays a strong positive correlation.

With this in mind, table 3 estimates how emigration over the full sample period is related to growing season frost shocks in 1864-67, proximity to the nearest emigration port, and our instrument: the interaction 
TABLE 3

First Stage: OLS Regressions

\begin{tabular}{|c|c|c|c|c|}
\hline & \multicolumn{4}{|c|}{ DePENDENT VARIABLE: EMigRATION 1867-1920 } \\
\hline & (1) & (2) & (3) & (4) \\
\hline \multirow[t]{2}{*}{ 1. Shocks $\times$ proximity to port } & $.0635^{* * *}$ & $.0623 * * *$ & $.0632 * * *$ & $.0621 * * *$ \\
\hline & $(.0157)$ & $(.0134)$ & $(.0135)$ & $(.0147)$ \\
\hline \multirow[t]{2}{*}{ 2. Shocks } & .0036 & $.0119 *$ & .0095 & .0073 \\
\hline & $(.0061)$ & $(.0063)$ & $(.0085)$ & $(.0107)$ \\
\hline \multirow{2}{*}{ 3. Shocks $\times$ proximity to trade port } & & & -.0127 & -.0098 \\
\hline & & & $(.0209)$ & $(.0200)$ \\
\hline \multirow[t]{2}{*}{ 4. Shocks $\times$ proximity to town } & & & .0019 & .0022 \\
\hline & & & $(.0045)$ & $(.0044)$ \\
\hline \multirow[t]{2}{*}{ 5. Shocks NGS $\times$ proximity to port } & & & & -.0004 \\
\hline & & & & $(.0162)$ \\
\hline \multirow[t]{2}{*}{ 6. Shocks NGS } & & & & .0079 \\
\hline & & & & $(.0130)$ \\
\hline County fixed effects & Yes & Yes & Yes & Yes \\
\hline Controls & No & Yes & Yes & Yes \\
\hline$p$-value $\beta($ row 1$)=\beta($ row 3$)=\beta($ row 4$)$ & & & .0007 & .0018 \\
\hline$p$-value $\beta($ row 1$)=\beta($ row 5$)$ & & & & .0225 \\
\hline Observations & 2,359 & 2,359 & 2,359 & 2,359 \\
\hline Mean dependent variable & 5.39 & 5.39 & 5.39 & 5.39 \\
\hline
\end{tabular}

NotE.-This table displays the effect on log emigration 1867-1920 of growing season frost shocks 1864-67 interacted with proximity to the nearest emigration port. Proximity is defined as minus the log of distance. Shocks NGS indicate frost shocks occurring in the nongrowing season. All regressions include county fixed effects and control for the log of the population at baseline. Additional control variables are log area, latitude, longitude, proximity to the nearest town, nearest trade port, nearest weather station, and Stockholm, as well as an urban indicator and a set of indicators for high soil quality for the production of barley, oats, wheat, dairy, and timber. Standard errors (in parentheses) are clustered at the weather station level.

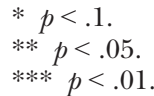

between the two. Consistent with the notion that individuals take the internal migration cost into account in their decision to emigrate (see, e.g., Sjaastad 1962), the results in column 1 indicate that over the 18671920 period, individuals in municipalities that are closer to a port emigrate more in response to an additional frost shock. The estimate implies that a one standard deviation increase in our instrument increases emigration by 14 percent. Alternatively, given one frost shock, a standard deviation increase in port proximity increases emigration by 6.3 percent. This result is robust to the inclusion of pre-emigration control variables in column 2.

We next consider a potential threat to the exclusion restriction. If frost shocks have a different economic impact depending on port proximity (which can proxy for local market access and economic characteristics), our instrument may capture differences in the economic impact of the shocks. For example, municipalities that are closer to Gothenburg or 
Malmö may have less weather-dependent economies if they have better access to insurance or rely less on agriculture. If so, the instrument would not only predict emigration but also capture the intensity of economic effects caused by the frost. This could have direct effects on our outcomes of interest, leading to a violation of the exclusion restriction. To control for this possibility, column 3 controls for the interaction between frost shocks and our two measures of market access: the proximity to the nearest town and the proximity to the nearest major trade port. The coefficient on the instrument is not sensitive to this adjustment. The interaction terms themselves are also not significantly different from zero. Moreover, a formal test rejects the null hypothesis that the interaction terms with emigration ports, trade ports, and towns are equal, with a $p$-value of .0007. Frost shocks therefore affect emigration only when interacted with travel costs, indicating that the instrument captures migrationrelated push factors only at the onset of mass emigration. Table A.6 presents additional estimates using the panel variation in emigration and frost shocks and controlling for municipality and year fixed effects. It shows that yearly frost shocks interacted with port proximity predict yearly emigration flows, but only during the first wave of mass emigration. From 1880 to 1920 , neither frost shocks nor the interaction with port proximity matters. The importance of both frost shocks and port proximity hence diminishes over time, in line with the finding in Thomas (1941) that later harvest shocks did not cause additional emigration. Both variables that compose our instrument can thus be thought of as capturing variation that was relevant only during the first wave of mass emigration. In Section IX, we perform placebo tests using the interaction between port proximity and frost shocks occurring during all 4-year periods other than 1864-67.

To provide support for the claim that frost shocks affect emigration through their impact on the agricultural sector, column 4 additionally includes nongrowing season frost shocks and their interaction with port proximity. ${ }^{46}$ The coefficient of the interaction term is substantially smaller and statistically indistinguishable from zero, thus mirroring the null effect found for agricultural outcomes. A formal test also rejects the null hypothesis that our instrument and its nongrowing season variant have the same coefficient. Growing season shocks therefore identify economically meaningful events and not spurious correlations with underlying variables at the municipality, such as general climatic conditions or fixed effects related to port proximity.

Figure 8 displays the first-stage relationship nonparametrically. In panel A, residuals of log emigration during 1867-1920 and the instrument are plotted after controlling for the full set of covariates. Municipalities

${ }^{46}$ Nongrowing season frost shocks over the period are defined analogously to growing season frost shocks. 

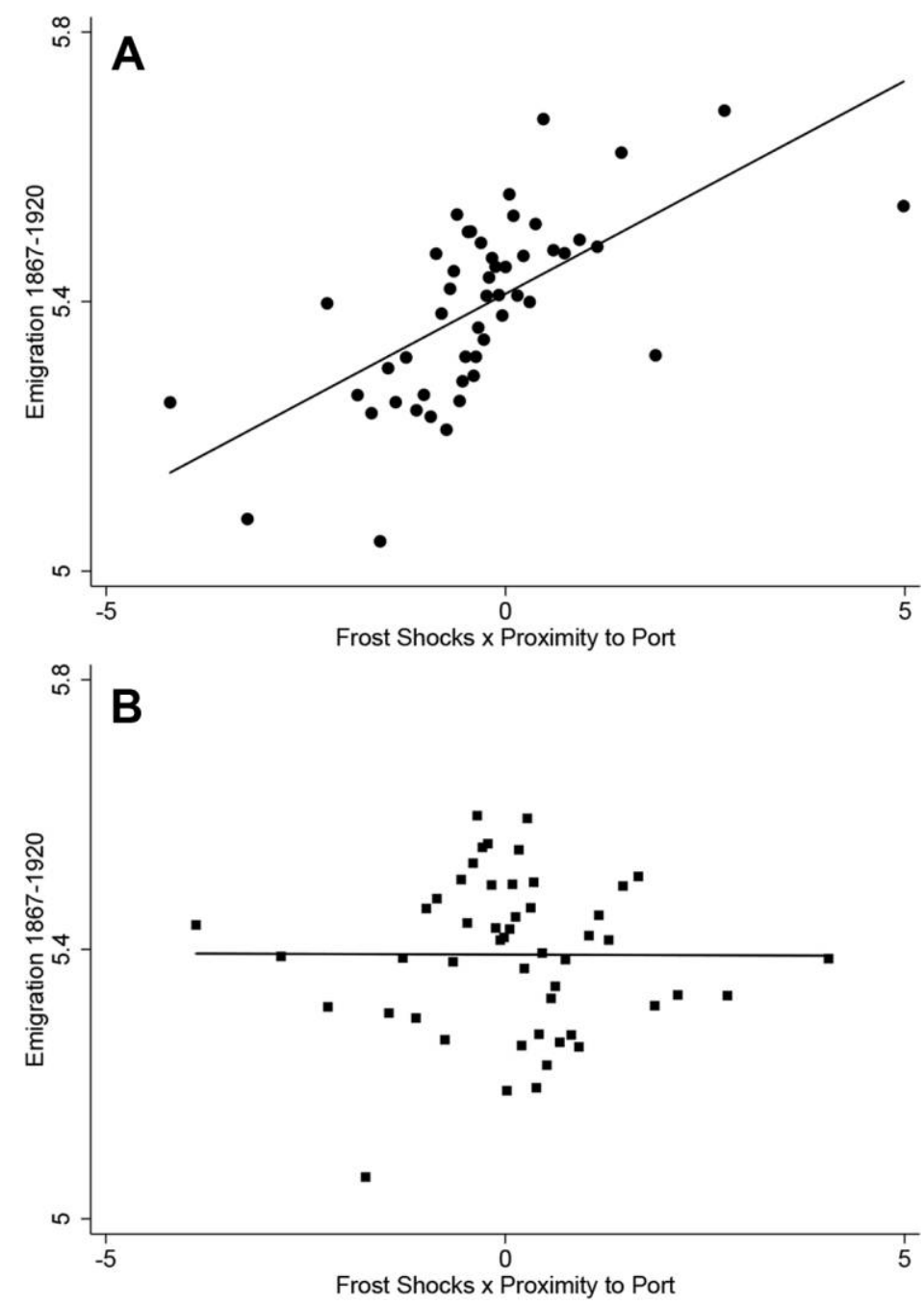

FIG. 8.-First-stage relationship nonparametrically. Panel A plots log total emigration during 1867-1920 against the instrument, defined as the interaction between the number of growing season frost shocks in 1864-67 and proximity to the nearest emigration port. Proximity is defined as minus the log of distance. Panel B instead shows the effect of nongrowing season shocks occurring in the same period. Municipalities are sorted into 50 groups of equal size. Dots indicate the mean value in each group. A linear regression line based on the underlying (ungrouped) data is also shown. Included controls are county fixed effects, frost shocks in 1864-67, proximity to the nearest emigration port, nearest trade port, nearest weather station, nearest town, and Stockholm, $\log$ population in $1865, \log$ area, latitude, longitude, arable land share in 1810, and indicators for urban municipalities and high soil suitability for the production of barley, oats, wheat, dairy, and timber. Panel B additionally controls for growing season frost shocks in 1864-67 and the instrument. 
are collected in 50 groups of equal size, with dots representing the mean value in each group. The figure shows that across the whole range of the instrument, observations are clustered near the regression line. ${ }^{47}$ The even distribution of group means indicates that there is compliance with the instrument at all values and that the log-linear specification with emigration in logs is an appropriate model. In panel B, we display the effect of the placebo instrument on migration using the specification in column 4 of table 3. As expected, the figure shows that emigration has no apparent relationship with the placebo instrument, whether linear or nonlinear.

Having established the importance of the initial frost shocks for emigration over the whole mass migration period, we next estimate the elasticity of later emigration with respect to first-wave emigration. Table A.7 estimates the effect of first-wave migration, 1867-79, on later waves of migration. The displayed results indicate an intertemporal elasticity of emigration near unity, confirming the canonical finding in the migration literature of strong path dependence in migration patterns referred to earlier.

\section{Emigration and Citizens' Demand for Political Change}

This section estimates the effect of emigration on citizens' demand for political change across Swedish municipalities. The main variable of interest is membership in the labor movement, given that unions and the Social Democratic Party were the strongest proponents of political change during our period of study and were directly involved in conflicts with economic and political elites at both local and national levels.

\section{A. Labor Movement Membership}

The Social Democratic Party was founded in 1889. Modern labor unions had become more widespread in the preceding decade, ultimately leading to the formation of the Swedish Confederation of Trade Unions in 1898. Table 4 displays reduced-form estimates of the effect of frost shocks on municipal labor movement membership rates between 1900 and 1920 . The instrument has a positive and statistically significant effect on the labor movement. Both market access interactions have negative estimates, and only one is statistically significant (at the 10 percent level). As in table 3 , a formal test rejects the null hypothesis that the instrument and market access interactions have equal coefficients. Additionally, nongrowing season frost shocks interacted with port proximity do not have a significant effect on the labor movement, and we can formally reject that the co-

\footnotetext{
${ }_{47}$ The slope of the regression line corresponds to the estimate in col. 3 of table 3 .
} 
TABLE 4

Reduced-Form EfFect on Labor Organization: OLS Regressions

\begin{tabular}{|c|c|c|c|c|}
\hline & \multicolumn{4}{|c|}{$\begin{array}{c}\text { DEPENDENT VARIABle: } \\
\text { LABOR ORGanization Rate 1900-1920 }\end{array}$} \\
\hline & (1) & (2) & (3) & (4) \\
\hline 1. Shocks $\times$ proximity to port & $\begin{array}{l}.0014 * * * \\
(.0004)\end{array}$ & $\begin{array}{l}.0014 * * * \\
(.0004)\end{array}$ & $\begin{array}{l}.0015^{* * * *} \\
(.0003)\end{array}$ & $\begin{array}{l}.0017 * * * \\
(.0004)\end{array}$ \\
\hline 2. Shocks & $\begin{array}{l}.0001 \\
(.0003)\end{array}$ & $\begin{array}{c}-.0001 \\
(.0003)\end{array}$ & $\begin{array}{c}-.0003 \\
(.0003)\end{array}$ & $\begin{array}{c}-.0001 \\
(.0003)\end{array}$ \\
\hline 3. Shocks $\times$ proximity to trade port & & & $\begin{array}{c}-.0009 * \\
(.0005)\end{array}$ & $\begin{array}{c}-.0012 * \\
(.0006)\end{array}$ \\
\hline 4. Shocks $\times$ proximity to town & & & $\begin{array}{c}-.0003 \\
(.0003)\end{array}$ & $\begin{array}{c}-.0004 \\
(.0003)\end{array}$ \\
\hline 5. Shocks NGS $\times$ proximity to port & & & & $\begin{array}{c}-.0003 \\
(.0004)\end{array}$ \\
\hline 6. Shocks NGS & & & & $\begin{array}{r}-.0009 \\
(.0004)\end{array}$ \\
\hline County fixed effects & Yes & Yes & Yes & Yes \\
\hline $\begin{array}{l}\text { Controls } \\
p \text {-value } \beta(\text { row } 1)=\beta(\text { row } 3)=\beta(\text { row } 4) \\
p \text {-value } \beta(\text { row } 1)=\beta(\text { row } 5)\end{array}$ & No & Yes & $\begin{array}{c}\text { Yes } \\
.0000\end{array}$ & $\begin{array}{r}\text { Yes } \\
.0001 \\
.0035\end{array}$ \\
\hline Observations & 2,358 & 2,358 & 2,358 & 2,358 \\
\hline
\end{tabular}

Note.- This table displays the effect of growing season frost shocks 1864-67 interacted with proximity to the nearest emigration port on the average labor organization rate 1900 1920. Proximity is defined as minus the log of distance. Shocks NGS indicate frost shocks occurring in the nongrowing season. All regressions include county fixed effects and control for the log of the population at baseline. Additional control variables are log area, latitude, longitude, proximity to the nearest town, nearest trade port, nearest weather station, and Stockholm, as well as an urban indicator and a set of indicators for high soil quality for the production of barley, oats, wheat, dairy, and timber. Standard errors (in parentheses) are clustered at the weather station level.

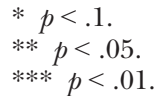

efficient is equal to that of the instrument. Table B.4 shows that nongrowing season shocks do not affect any of our other outcome variables.

To verify the robustness of our results, we also graphically display nonparametric estimates of the reduced-form relationships. Figure 9 plots the instrument against emigration during 1867-1900 (the first stage) and labor movement membership during 1900-1920 (the reduced form). All variables are residualized using the full set of covariates. We see that both outcomes are positively correlated with the instrument across the entire range of its values. Taken together, these results imply a positive relationship between emigration and labor movement membership.

Table 5 reports OLS and IV regression results using the average labor movement membership rate between 1900 and 1920 as the dependent variable. In the two specifications in columns 4 and 5, the estimated IV coefficients are strongly significant and stable at approximately 0.021 , including when we control for predetermined municipal characteristics. 


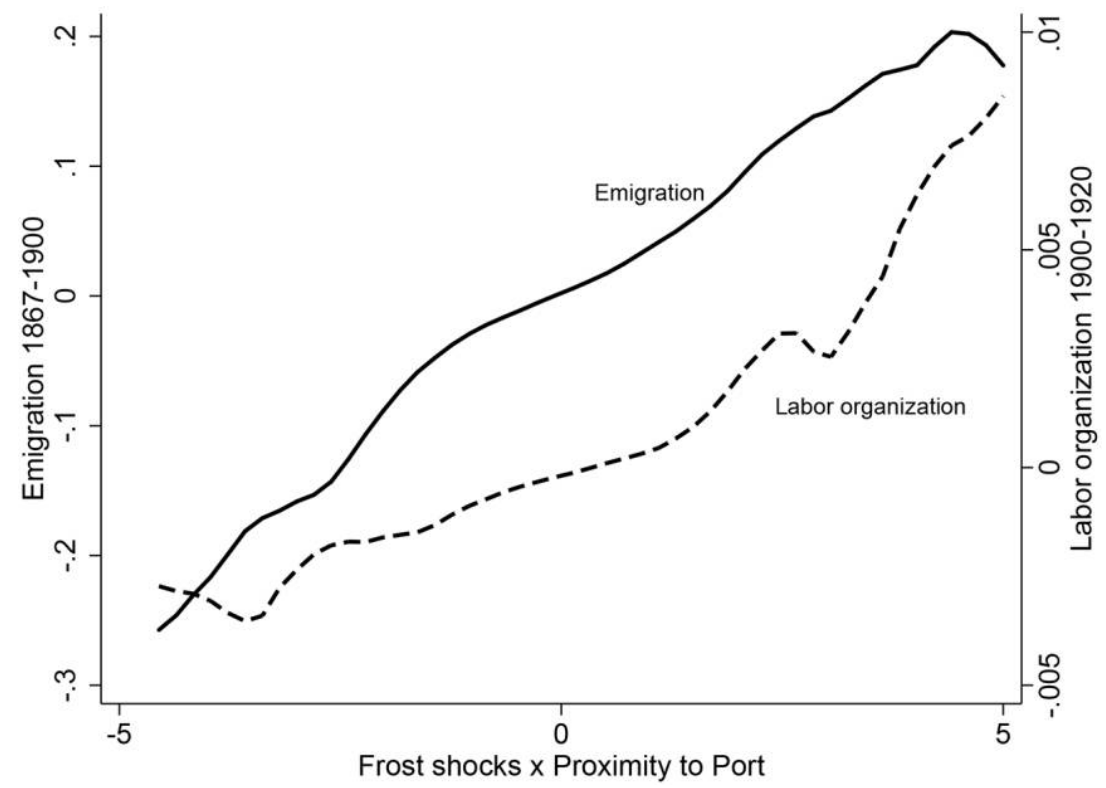

FIG. 9.-Nonparametric reduced-form relationships. Local mean smooth. Bandwidth: 1. This figure nonparametrically displays the first-stage relationship, as well as the reducedform effect of the instrument on the average labor organization rate for 1900-1920. The instrument is the interaction between the number of growing season frost shocks for 1864 67 and proximity to the nearest emigration port. Proximity is defined as minus the log of distance. All variables have been residualized using the following covariates: county fixed effects, the $\log$ of the population at baseline, $\log$ area, latitude, longitude, proximity to the nearest emigration port, nearest town, nearest trade port, nearest weather station, and Stockholm, the number of growing season frost shocks in 1864-67, the interaction between growing season frost shocks and proximity to the nearest town and trade port, as well as an urban indicator and a set of indicators for high soil quality for the production of barley, oats, wheat, dairy, and timber. Sixteen observations that have IV residual values above 5 have been top coded at 5 to reduce noise.

Column 6 includes the two market access interactions, using proximity to the nearest trade port and town to control for potential violations of the exclusion restriction. The point estimate becomes slightly larger with these controls and remains significant at the 1 percent level. This indicates that the instrument is not correlated with the economic impact of frost shocks in a meaningful way. Moreover, it indicates that the market access effect leads to, if anything, a downward bias on our estimates. ${ }^{48}$

The point estimates are large. The preferred estimate in column 6 suggests that a municipality that doubles its emigration over a 30 -year period

${ }^{48}$ Section IX performs several robustness tests to support the validity of the exclusion restriction. We vary the towns and trade ports that are used to create the market access variables, use pre-emigration agricultural variables as a separate test, and perform sensitivity analysis using the method of Conley et al. (2012). 
TABLE 5

The EfFect of Emigration on Labor Organization

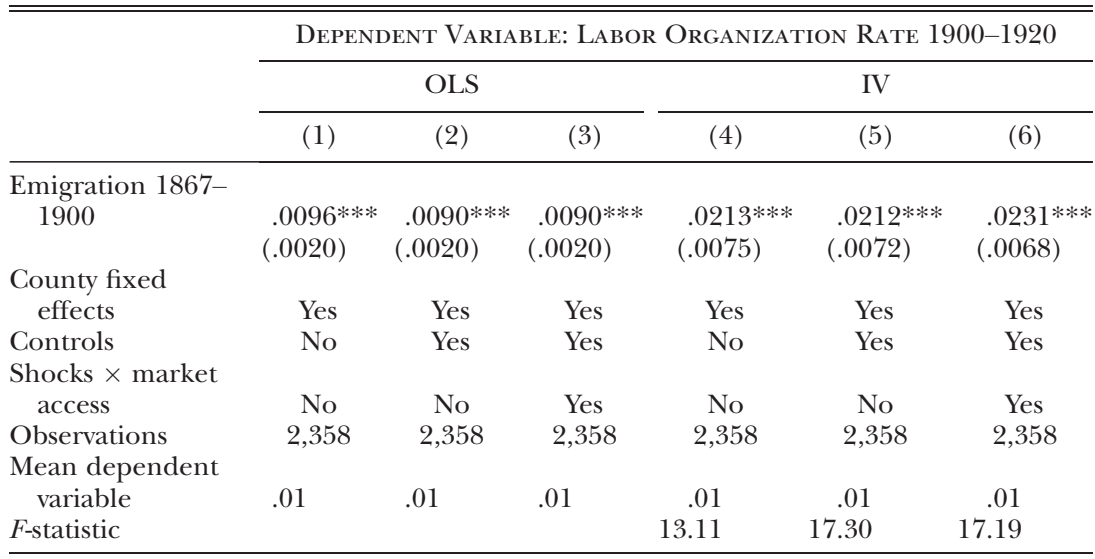

NotE.-This table displays the effects of log emigration 1867-1900 on the average labor organization rate 1900-1920. The excluded instrument is the interaction between the number of growing season frost shocks $1864-67$ and proximity to the nearest emigration port. Proximity is defined as minus the log of distance. All regressions include county fixed effects and control for the log of the population at baseline. Additional control variables are growing season frost shocks 1864-67, proximity to the nearest emigration port, nearest town, nearest trade port, nearest weather station, and Stockholm, log area, latitude, longitude, as well as an urban indicator and a set of indicators for high soil quality for the production of barley, oats, wheat, dairy, and timber. Shocks $\times$ market access includes the interaction between growing season frost shocks and proximity to the nearest town and trade port, respectively. The $F$-statistic refers to the excluded instrument. Standard errors (in parentheses) are clustered at the weather station level.

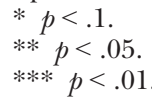

increases the local labor movement membership by 2.3 percentage points. The effect size corresponds to moving a municipality from the mean to the 90th percentile of the distribution of membership rates. The IV coefficients are also just more than twice as large as the corresponding OLS estimates. The difference implies a downward bias in OLS and that OLS estimates provide a lower bound on the effect of emigration on labor movement size. A possible reason for this is that emigration was more common in regions that were also less likely to develop labor organizations, perhaps where landlords and employers were particularly powerful. This would be consistent with bad institutions acting as a push factor for emigrants. Measurement error in emigration may, in addition, be contributing to the difference in estimates.

To complement the analysis above, we trace out the impact of emigration on labor movement membership every 5 years between 1890 and 1920 in figure C.1. Starting in 1900, emigration has a clear positive and statistically significant effect on labor organization rates. We first detect 
significant effects starting in 1900 likely as a result of Sweden's comparably late industrialization, which meant that the labor movement started late as well. ${ }^{49}$ The effect sizes show an increasing trend, which mirrors the general positive trend in membership rates in the period. Interestingly, the effect grows over time even as emigration rates dropped during World War I. This may reflect the possibility that, once established, unions could more easily attract members and became less reliant on the emigration threat.

We next study the effect of emigration on a direct, costly action directed toward employers. In response to a downturn in the business cycle in 1909, the Swedish Employers Association sought to lower workers' wages. Anticipating opposition by labor organizations, it enacted a lockout of thousands of workers in order to force acceptance from the unions. The Swedish Confederation of Trade Unions instead responded by calling a general strike, affecting 300,000 laborers who halted work for 3 months. Using data on strike participation by municipality, we estimate the effect of emigration on the mobilization of workers in table $6 .{ }^{50}$ If our estimated effect on labor movement size indeed captures a greater ability to organize and mobilize citizens, we should expect high-emigration municipalities to display a greater participation in the strike. ${ }^{51}$ This is confirmed by the result in column 1, which shows a positive and significant effect. Membership in the labor movement not only was ceremonial then but also resulted in an effective collective action. A 10 percent increase in emigration implies a 0.32 percentage point higher strike participation.

We next study the effect of emigration on the share of strikers that were unionized, as this provides a more direct indicator of the labor movement's role in strike participation. Municipalities that did not participate in the strike are assigned a value of 0.5 , indicating the same number of unionized as non-unionized strikers. The positive estimate in column 2 of table 6 indicates that emigration causes a greater share of union members among strikers. Approximately 9 percent of the municipalities that participated in the strike had more non-unionized than unionized strikers. Given that strikes were the most common tool available for political and economic protests (Westerståhl 1945), this finding suggests that em-

\footnotetext{
${ }^{49}$ In 1890 , there were 2,308 labor movement members in Sweden, while there were 75,724 in 1900 .

${ }_{50}$ The number of emigrants is always summed from 1867 until the year in which the outcome is measured. In table B.17, we also show results in which emigration is counted between 1867 and 1900 for all outcomes.

${ }^{51}$ Although the willingness to participate in strikes could be independent of union membership, or even negatively related, it is well established that the Swedish labor unions were deeply involved in the 1909 strike. In general, similarly to their German counterparts, Swedish labor unions used strikes as their principal tool for protests (see, e.g., Westerståhl 1945).
} 
TABLE 6

Mobilization of Workers and Electoral Outcomes: IV Regressions

\begin{tabular}{|c|c|c|c|c|c|c|c|}
\hline & \multicolumn{7}{|c|}{ DEPENDENT VARIABLE } \\
\hline & \multicolumn{2}{|c|}{ General Strike 1909} & \multicolumn{3}{|c|}{ Electoral Outcomes 1911-21 } & \multicolumn{2}{|c|}{$\begin{array}{c}\text { Left-Wing Share } \\
\text { 1998-2014 }\end{array}$} \\
\hline & $\begin{array}{l}\text { Strikers } \\
\text { per } \\
\text { Capita } \\
(1)\end{array}$ & $\begin{array}{c}\text { Share } \\
\text { Unionized } \\
\text { Strikers } \\
(2)\end{array}$ & $\begin{array}{l}\text { Left-Wing } \\
\text { Vote } \\
\text { Share } \\
(3)\end{array}$ & $\begin{array}{l}\text { Turnout } \\
\text { (4) }\end{array}$ & $\begin{array}{l}\text { Eligible } \\
\text { Voters } \\
(5)\end{array}$ & $\begin{array}{c}\text { Municipal } \\
\text { Elections } \\
(6)\end{array}$ & $\begin{array}{c}\text { National } \\
\text { Elections } \\
(7)\end{array}$ \\
\hline \multicolumn{8}{|l|}{ Emigration } \\
\hline $1867-$ & $\begin{array}{l}.0319 * * \\
(.0127)\end{array}$ & $\begin{array}{l}.0440 * * \\
(.0176)\end{array}$ & $\begin{array}{l}.1204 * * \\
(.0494)\end{array}$ & $\begin{array}{l}.0805^{* *} \\
(.0342)\end{array}$ & $\begin{aligned}- & -.0962 \\
& (.0804)\end{aligned}$ & $\begin{array}{l}.0818^{* *} \\
(.0368)\end{array}$ & $\begin{array}{l}.0744 * * \\
(.0336)\end{array}$ \\
\hline $\begin{array}{l}\text { County fixed } \\
\text { effects }\end{array}$ & Yes & Yes & Yes & Yes & Yes & Yes & Yes \\
\hline Controls & Yes & Yes & Yes & Yes & Yes & Yes & Yes \\
\hline $\begin{array}{c}\text { Shocks } \times \\
\text { market } \\
\text { access }\end{array}$ & Yes & Yes & Yes & Yes & Yes & Yes & Yes \\
\hline Observations & 2,358 & 2,359 & 2,359 & 2,359 & 2,358 & 2,358 & 2,354 \\
\hline $\begin{array}{l}\text { Mean } \\
\text { dependent } \\
\text { variable }\end{array}$ & .01 & .04 & .25 & .60 & .31 & .36 & .38 \\
\hline$F$-statistic & 19.88 & 19.84 & 20.95 & 20.95 & 20.96 & 24.94 & 25.02 \\
\hline
\end{tabular}

Note.-Col. 1 reports the effects of emigration on participation in the 1909 general strike. The dependent variable in col. 2 is the share of strikers who were union members. Municipalities with no strikers are assigned a value of 0.5 . The outcome in col. 3 is the average vote share of the Social Democratic and Socialist Parties, while cols. 4 and 5 use voter turnout and the share of eligible voters per capita, respectively. The outcomes in cols. 6 and 7 are the average vote share of the Social Democratic and Socialist Parties 19982014 in municipal and national elections. The excluded instrument in all models is the interaction between the number of growing season frost shocks $1864-67$ and proximity to the nearest emigration port. Proximity is defined as minus the log of distance. All regressions include county fixed effects and control for the log of the population at the baseline. Additional control variables are growing season frost shocks 1864-67, proximity to the nearest emigration port, nearest town, nearest trade port, nearest weather station, and Stockholm, log area, latitude, longitude, as well as an urban indicator and a set of indicators for high soil quality for the production of barley, oats, wheat, dairy, and timber. Shocks $\times$ market access includes the interaction between growing season frost shocks and proximity to the nearest town and trade port, respectively. The $F$-statistic refers to the excluded instrument. Standard errors (in parentheses) are clustered at the weather station level.

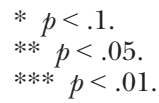

igration developed a stronger bargaining position of citizens, through its effect on the labor movement. ${ }^{52}$

\section{B. Electoral Effects}

The Social Democratic Party had strong ties with labor unions, and the central Confederation of Trade Unions in particular, each side making

${ }^{52}$ While the 1909 general strike was not considered a victory for the labor movement, strikes often resulted in favorable outcomes for workers. Summary evidence on 748 strikes 
up one leg of the Swedish labor movement. The greater local membership of labor unions made them interesting for the Social Democrats, who saw a way of expanding the local penetration of socialist ideas. Unions indeed participated in election campaigns for the Social Democrats, and a large fraction of voters for the left are thought to have come from labor union members (Westerståhl 1945). Having established that emigration increased labor organization and striking, we therefore proceed to test if the relationship also extends to electoral mobilization. For this purpose, we look at turnout rates and support for left-wing parties in national elections between 1911 and 1921. This period ranges from the first election with mandatory party affiliations to the first election with universal suffrage.

Table 6 reports regression results for the effect of emigration on the average vote share of the Social Democratic and Socialist Parties between 1911 and 1921. The IV estimate in column 3 indicates that an increase in emigration by 10 percent increased the vote share of the left by 1.2 percentage points. Figure C.2 displays the IV coefficients for each election in separate regressions. Overall, emigration led to significantly greater support for left-wing parties. The effect is strongest in the earliest elections, possibly indicating catch-up among low-emigration municipalities over time as suffrage was gradually expanded.

Until 1921, voting eligibility was reserved for men who had paid their taxes, who were not in poverty care or bankruptcy, and who had performed their military service. These restrictions disenfranchised one-fifth of otherwise voting-eligible men (Grenholm et al. 1985). Nevertheless, even during a time when only relatively well-off men could vote, there is a shift in party preferences toward left-wing parties.

Finally, column 4 of table 6 displays regression results for the effect of emigration on average voter turnout during the period. We find positive effects on turnout, with an estimate indicating that a 10 percent increase in emigration increases the voter turnout by approximately 0.8 percentage points, from an average of 60 percent during the period. This result suggests a complementary role of labor organizing and voting, in line with the goal of the Social Democratic Party of using local organizations to mobilize citizens for larger, nationwide political change. It is relevant to note that the increase in the left-wing vote share cannot be explained by an increased mobilization of poor voters, as the vote share is computed using the total number of votes in the denominator.

\section{Persistence of Electoral Effects}

Using data on both national and municipal elections from the five most recent election rounds, 1998-2014, we estimate the persistence of emi-

during 1863-1902 found that strikes resulted in concessions to workers' demands in 47 percent of the cases, while 32 percent of the cases ended in a compromise and only 20 percent sided with the employers (Kommerskollegii 1909). 
gration on left-wing voting. Columns 6 and 7 of table 6 display IV estimates using emigration from 1867 until 1945, after which emigration was uncommon. Strikingly, the results show that the emigration sparked by frost shocks in the 1860s has significant effects on voting up to the five latest Swedish elections. The results are stronger in municipal elections than in national elections, possibly because of contemporary issues at the national level having a stronger influence compared to tradition. The estimate in column 7 of 0.074 is a bit over half as large as the corresponding estimate for the 1911-21 elections. The mean vote share of the left is also higher in the later period, that is, 38 percent rather than 24 percent.

\section{Emigration and Local Government Policy Making}

The results in the previous sections show that emigration increased the political organization and mobilization of citizens during the Age of Mass Migration. This section tests if these changes were also reflected in local government policy making by looking at welfare expenditures and local political institutions.

\section{A. Welfare Expenditures}

We use welfare expenditures as a measure of redistributive actions taken by local governments. Municipalities had the power to tax their residents and set their own tax rate. Taxation was progressive, as only the relatively rich paid taxes. On average, these taxes averaged more than 90 percent of municipal income in 1910. Welfare spending constituted about 20 percent of municipal budgets and included support for unemployed, disabled, elderly, and widows. The choice of expenditures can also be seen as an equilibrium outcome of bargaining between elites, who hold political power, and citizens. We study per capita expenditures on welfare in 1918, 1 year before democratization, and in 1919, immediately afterward. In 1918, municipal voting was restricted by wealth, income, and property ownership. Votes were also weighted by a factor of up to 40 in favor of richer voters (Nilsson 1964).$^{53}$ As a result, formal authority over spending levels was heavily biased in favor of economic elites in 1918. Changes in policy at this time are thus reflective of their choices rather than those of common citizens. This can be quantified by comparing average welfare spending before and after democracy: in 1918 it was SEK 2.42 per capita (in 1918 Swedish kronor) while it rose in real terms by 13 percent to SEK 2.74 in 1919 as ordinary citizens could vote.

${ }^{53}$ In 1905, 1 percent of the rural population held as many votes as the remaining 99 percent (Nilsson 1964). The cap on votes was 1,000 at that time, however, rather than 40 . 
TABLE 7

Policy Responses to Emigration: IV Regressions

\begin{tabular}{|c|c|c|c|c|}
\hline & \multicolumn{4}{|c|}{ DEPENDENT VARIABLE } \\
\hline & \multicolumn{2}{|c|}{ Expenditures per Capita } & \multicolumn{2}{|c|}{ Representative Democracy } \\
\hline & $\begin{array}{c}1918 \\
(1)\end{array}$ & $\begin{array}{c}1919 \\
(2)\end{array}$ & $\begin{array}{c}1919 \\
(3)\end{array}$ & $\begin{array}{c}1938 \\
(4)\end{array}$ \\
\hline Emigration 1867- & $\begin{array}{l}.9964 * * * \\
(.3612)\end{array}$ & $\begin{array}{l}1.1163 * * * \\
(.3332)\end{array}$ & $\begin{array}{l}.0473 * * \\
(.0221)\end{array}$ & $\begin{array}{l}.1518 * * \\
(.0655)\end{array}$ \\
\hline County fixed effects & Yes & Yes & Yes & Yes \\
\hline Controls & Yes & Yes & Yes & Yes \\
\hline Shocks $\times$ market access & Yes & Yes & Yes & Yes \\
\hline Observations & 2,219 & 2,203 & 2,221 & 2,208 \\
\hline Mean dependent variable & 2.41 & 2.76 & .02 & .13 \\
\hline$F$-statistic & 16.35 & 15.64 & 15.62 & 18.15 \\
\hline
\end{tabular}

Note.-This table displays the effects of emigration on per capita welfare expenditures in 1918 and 1919, as well as on the voluntary adoption of representative democracy by 1919 and by 1938. The excluded instrument is the interaction between the number of growing season frost shocks $1864-67$ and proximity to the nearest emigration port. Proximity is defined as minus the $\log$ of distance. All regressions include county fixed effects and control for the $\log$ of the population at baseline. Additional control variables are growing season frost shocks $1864-67$, proximity to the nearest emigration port, nearest town, nearest trade port, nearest weather station, and Stockholm, log area, latitude, longitude, as well as a set of indicators for high soil quality for the production of barley, oats, wheat, dairy, and timber. Shocks $\times$ market access includes the interaction between growing season frost shocks and proximity to the nearest town and trade port, respectively. Cols. 3 and 4 include a set of dummy variables taking the value of one if the municipal population was 1,500 or higher in 1918 (col. 3) or in each year 1918-37 (col. 4). The $F$-statistic refers to the excluded instrument. Standard errors (in parentheses) are clustered at the weather station level.

$$
\begin{aligned}
& * p<.1 . \\
& * * p<.05 . \\
& * * * \quad p<.01 .
\end{aligned}
$$

Table 7 displays our results. Column 1 shows that emigration leads to a significantly higher per capita expenditure in 1918, 1 year before democracy was introduced. ${ }^{54}$ As documented in column 2 , the effects on welfare spending remain in 1919, as voting rights were extended on an equal basis. ${ }^{55}$ The estimate is somewhat larger than in 1918 and indicates that a doubling of emigration leads to approximately SEK 1.1 higher expenditures per capita in 1919, an increase of 40 percent over the mean. Overall, both before and after citizens had the formal power of affecting welfare policy in municipalities, emigration led to higher levels of redistribution.

${ }^{54}$ Table C.5 displays full regressions. The IV estimate is stable when excluding baseline and market access controls.

${ }_{55}$ Since we find that emigration slightly affects the average age downward over time, it is unlikely that the increase in welfare expenditures is driven by an increase in the elderly population. 
OOO

\section{B. Political Institutions}

Starting in 1919, rural local governments could adopt two different institutions for decision making, direct or representative democracy. Earlier, all municipalities had been direct democracies. In direct democratic municipalities, public town meetings would be held at least three times a year to decide on economic matters. Deliberations were public and decisions were typically made by a voice vote. By contrast, in municipalities of the representative type, eligible citizens voted for their party of choice in closed elections. Starting in 1919, there was an assignment rule dictating that municipalities with more than 1,500 inhabitants adopt the representative form of government, whereas those below the threshold were free to choose between the two. In practice, however, only a small fraction of municipalities chose the representative form voluntarily. Hinnerich and Pettersson-Lidbom (2014) find that direct democracies implement substantially lower levels of welfare spending per capita, potentially because direct democracies are more easily captured by elites. This is partly seen by the low attendance rate at town meetings, 12 percent, whereas the voter turnout in national elections was routinely above 50 percent. The choice of institution was then to a large extent a choice about its inclusiveness, the relative power of elites, and the amount of redistribution.

We use data on the local form of democracy to test for the effect of emigration on institutional change. This is done by coding a dummy variable taking the value of one if the municipality was a representative democracy by 1919 or 1938 and had a population of 1,500 or less in the preceding year. The last condition is included to take into account only voluntary transitions from direct to representative government. We take this measure to be an indicator of the inclusiveness of local political institutions. In addition, we include as controls indicators for a municipality ever having crossed the population threshold in the preceding years.

Columns 3 and 4 of table 7 show that high-emigration municipalities were indeed more likely to adopt the more inclusive form of democracy in their local governments. The effects are statistically significant in 1919, the first year of the new assignment rule, with the coefficient implying a 4.7 percentage point increase in the likelihood of a representative democracy from a doubling of emigration. Column 4 shows that in 1938, when a larger share of municipalities had transitioned voluntarily, the effect is larger.

\section{Mechanisms}

To study the potential mechanisms behind these results, we draw on Kapur and McHale (2005) and explore four broad channels through which emigration may affect home country institutions. First, easier access to emi- 
gration can raise the outside options of those who stay behind, influencing bargaining between citizens and elites. Second, emigration may elicit local economic responses that in turn cause political change. Third, the selection of migrants may change the composition of people who remain in Sweden. Fourth, emigrants may transmit American attitudes to their countrymen at home.

While we cannot narrow the field down to one explanation to the exclusion of all others, we find evidence consistent with the notion that increased outside options played an important role by strengthening prospective migrants' bargaining power vis-à-vis elites. However, this does not rule out that additional mechanisms contribute to our results.

\section{A. Outside Options}

As living standards were higher in the United States as compared to Sweden, the option of migrating constituted an attractive possibility for many. It may have enabled workers to take higher risks, such as joining labor unions. We provide three pieces of evidence that together suggest that outside options are in fact higher in places with high past emigration. First, the strong and long-lasting chain migration, as evidenced in table A.7, is prima facie evidence of this. Well beyond the famine years, emigration rates did not converge but instead diverged as connected areas sent additional emigrants. By revealed preference, the continued emigration indicates that the outside option was higher than remaining in Sweden.

However, the observed chain migration could, for example, also be due to a desire to reunite with family. To identify the role of economic opportunities in raising outside options, we use panel variation and study changes in the value of the emigration option over time. It is well established that aggregate emigration in this period is correlated with the relative prosperity of the United States compared to Sweden (Bohlin and Eurinius 2010). We should therefore expect the value of the outside option created by migrant networks to fluctuate in accordance with these macro-level incentives for emigration. Correspondingly, table A.8 shows that yearly emigration rates during 1880-1920 match this cyclical pattern. Locations with more migrant networks, as predicted by our instrument, are more likely to emigrate during years when the United States-Sweden GDP difference is larger. Hence, the emigration option was specifically exercised when its value was high, indicating that material returns were important determinants of chain migration. This is consistent with contemporary evidence that living standards were a primary concern for prospective emigrants (Sundbärg 1913)

Finally, we study the response of high-emigration areas to the rise of a new outside option: migrating within Sweden. Internal migration became widespread as Sweden industrialized in the late nineteenth century, 
which brought an increase in higher-wage work opportunities (Jörberg 1972). Using the 1890 census, we define internal out-migration for municipality $m$ as the number of individuals who were born in $m$ but live in any other municipality. Urbanization is defined analogously as out-migration to urban municipalities. ${ }^{56}$ Columns 1 and 2 of table 8 show that locations with more emigrants were less likely to send migrants within Sweden. Even as workers all across Sweden migrated to other parts of the country to take advantage of the higher wages in the industrial sector, this option was apparently not attractive for those who could easily emigrate instead.

Contemporary accounts also lend support to the hypothesis that the outside option of emigration was of substantial value, eclipsing the choice of migrating internally. For example, Rondahl (1985) documents that emigration was a preoccupation among young residents of Ljusne. One labor organizer who had been fired for his activism remarked that "oddly enough, there [are] only two places in the world for us, Ljusne or America” (20), giving a particularly stark indication that internal migration was not considered an alternative. About Öland, which also had a strong emigration history, Nelson (1909) writes that prospective migrants showed little interest in other parts of Sweden. As family and friends promised good fortunes overseas, they almost considered America to be "the only labor market."

To explore the possibility that outside options also led to a greater bargaining strength of workers, we turn to study how emigration affected wages. For this purpose, we employ yearly data on low-skilled agricultural wages at the county level from Jörberg (1972). This is the only available disaggregated wage series for the period before World War I. It covers wages on agricultural day workers, who were essentially low-skilled and landless. Scattered across Sweden, these types of workers made up about half of the agricultural working class (Jungenfelt 1959), and their employment terms resembled those of industrial and construction workers (Enflo, Lundh, and Prado 2014). The wage series represents both urban and rural areas and reflects the level of low-skilled wages more in general (Ljungberg 1997). Table 9 documents the relationship between total emigration in 1867-1900 and long-run wage growth in 23 counties. Long-difference regression results in columns $1,2,5$, and 6 indicate that counties experiencing more emigration also saw considerably higher wage growth between 1860 and 1910. The same relationship is found when aggregating the instrument to the county level and estimating reduced-form impacts. This positive relationship is consistent with the findings of economic historians that the Swedish emigration increased wages (O'Rourke and Williamson 1995; Ljungberg 1997). Interestingly, this finding also has similarities

${ }^{56}$ Swedish industry is well known to have been located in both urban and rural areas, and hence both measures of internal migration are relevant (Thomas 1941). 


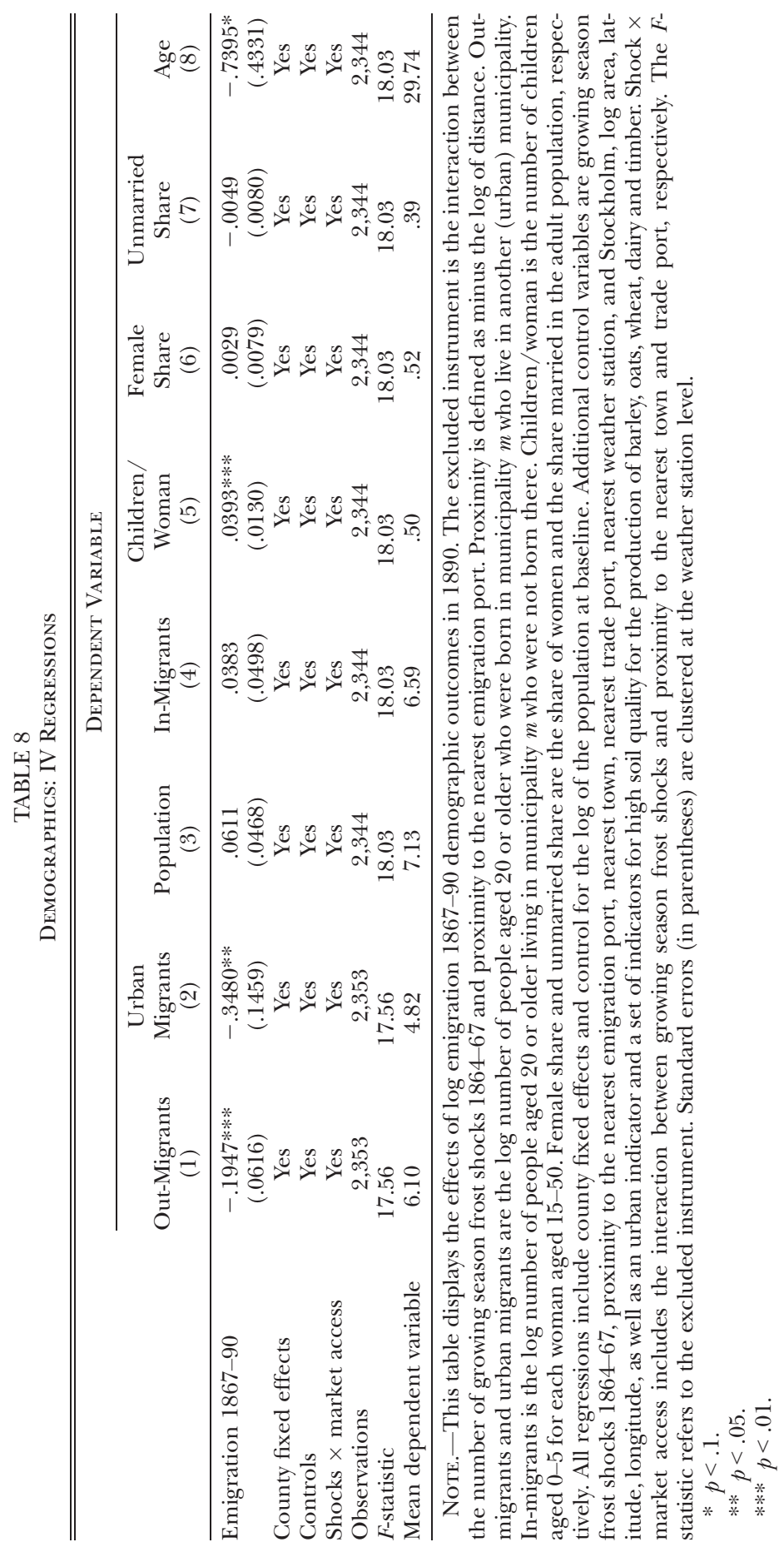

This content downloaded from 213.115.175.062 on June 19, 2019 01:33:57 AM All use subject to University of Chicago Press Terms and Conditions (http://www.journals.uchicago.edu/t-and-c). 


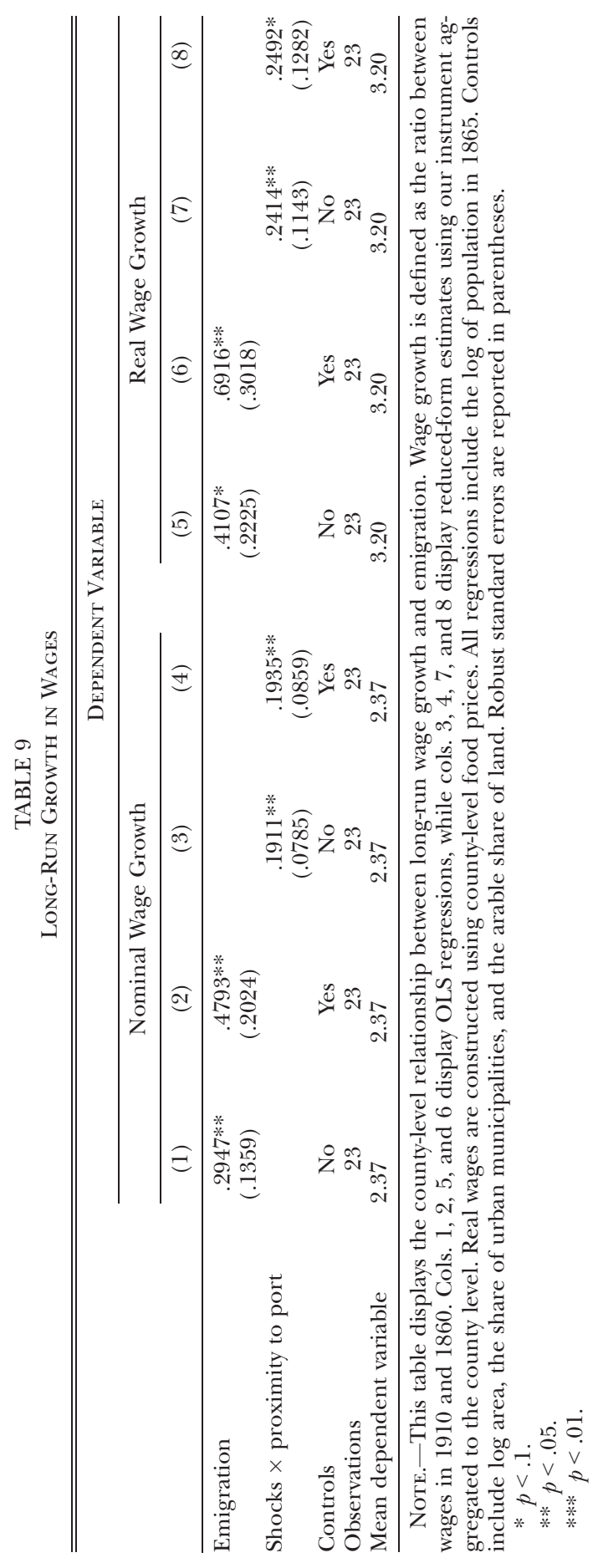

This content downloaded from 213.115.175.062 on June 19, 2019 01:33:57 AM 
with that of Habakkuk (1962). He argued that the possibility of migrating to the western frontier led to an increase in the wages of US workers on the East Coast, since agricultural land was cheap in the West and returns were high. Our results suggest that the westward migration of Swedes had a similar effect on wages in Sweden.

Why would better outside options increase labor union organization rates rather than simply improve individual bargaining? Theoretically, the choice to join a labor union has been modeled as a trade-off between the compensation premium provided by membership and the cost of being a member (see, e.g., Booth and Chatterji 1995; Holmlund and Lundborg 1999). The compensation premium may take the form of a wage premium or an excludable incentive good, for example, a grievance procedure. ${ }^{57}$ One way in which unions are able to provide a premium is by organizing and threatening strikes (Lindbeck and Snower 1986). The "strike weapon" was the primary method of activism used by the labor movement during our period of study (Westerståhl 1945) and is likely the mechanism through which unions were successful in bargaining. Additionally, the cost of union membership for a worker included not only membership fees but also the risk of employer retaliation in the form of firing, eviction, or blacklisting of union members.

Booth and Chatterji (1995) show that higher outside options for workers raise membership by improving wages, thereby increasing the expected utility of membership more than the expected utility of nonmembership. In our setting, to the extent that emigration opportunities improve outside options, the resulting increase in the union compensation premium should thus increase membership. Similarly, emigration can be used as a fallback option for workers facing a hostile employer, lowering the cost of union membership and therefore raising the incentive to become a member.

In addition to improving the bargaining position vis-à-vis employers, improved outside options may have bolstered the labor movement by increasing the returns to organizing, as political elites became more responsive to the demands of citizens. Section II.A described how economic and political elites demanded new policies to respond to the perceived threat that emigration posed to economic and political interests. In addition to the emigration threat, the labor movement brought with it a greater strike threat. In particular, as emigration rates dropped during World War I, the political effects of emigration may have been primarily driven by the presence of a strong local labor movement. The responsiveness of elites was displayed locally, with several municipalities recruiting labor movement representatives to the local administration (Östberg 1995), while left-wing candidates were sometimes included on larger parties' vot-

${ }^{57}$ The empirical literature suggests a wage premium of about $10-15$ percent (see, e.g., Budd and Na 2000; Hirsch 2004). 
ing lists by parties seeking to increase their representativeness (Lundkvist 1977).

\section{B. Local Economic Responses}

In the following section we consider if mass emigration affected local economic conditions and to what extent such effects are likely to explain the upswing in the labor movement. Population declines can have important effects on both labor relations and wages. Our data, however, indicate that lasting shifts to labor supply did not play an important role in our setting. As shown in column 3 of table 8 , the population as measured in the 1890 census was not significantly lower as a result of emigration. ${ }^{58}$ This perhaps surprising result is potentially explained by two factors. First, as shown above, emigration lowers the rate of internal migration (cols. 1 and 2). Second, emigration creates a fertility response, given by an increase in the number of young children per woman (col. 5). ${ }^{59}$ Together these factors explain a substantial part of the population response. For the average municipality, our reduced-form estimates indicate that a standard deviation increase in the instrument increases the population by 0.8 inhabitants for every emigrant, with internal migration being the most important factor. To further test the robustness of the effect on total population, we control for population growth between 1810 and 1865, before the emigration episode began. The coefficient remains insignificant with this additional control, as seen in table B.18. Moreover, the balance test in table 2 shows that the instrument is not correlated with pre-emigration population growth. Even though there were no population impacts in the longer term, it is, however, possible that short-term effects on labor scarcity may have had longer-term consequences.

The increase in low-skilled wages that we find above may be related to broader economic changes. In a companion paper, we find that the number of innovations, as measured by technological patents, increased in high-emigration municipalities (Andersson et al. 2017). Ljungberg (1997) argues that high wages, induced by emigration, produced incentives for a structural change toward the industrial sector. We indeed find that highemigration municipalities underwent faster structural change as compared to their low-emigration counterparts. Table 10 displays this finding. ${ }^{60}$ Using census data from 1910, we find that high-emigration municipalities had fewer farm workers and more industrial workers (cols. 2 and 3). In addi-

\footnotetext{
${ }^{58}$ OLS estimates, presented in table C.12, indicate a positive correlation.

${ }^{59}$ The fact that fertility adapts quickly is in line with recent evidence from Sweden showing that a reduction in infant mortality in the early nineteenth century caused population levels to remain stable rather than increase, because of a rapid decrease in fertility (Ager, Worm Hansen, and Sandholt Jensen 2017).

${ }^{60}$ Tables C.19-C.24 document that this relationship is present also in the OLS estimations.
} 
TABLE 10

ECONOMIC OUTCOMES: IV REgRESSIONS

\begin{tabular}{|c|c|c|c|c|c|c|}
\hline & \multicolumn{6}{|c|}{ DePENDENT Variable } \\
\hline & $\begin{array}{c}\text { Horses } \\
\text { per Area } \\
\text { (1) }\end{array}$ & $\begin{array}{c}\text { Farm } \\
\text { Workers } \\
(2)\end{array}$ & $\begin{array}{l}\text { Industrial } \\
\text { Workers } \\
(3)\end{array}$ & $\begin{array}{l}\text { Any } \\
\text { Firm } \\
(4)\end{array}$ & $\begin{array}{c}\text { Labor } \\
\text { Organization } \\
\text { per Industrial } \\
\text { Worker } \\
\quad(5)\end{array}$ & $\begin{array}{c}\text { Strikers per } \\
\text { Industrial } \\
\text { Worker } \\
(6)\end{array}$ \\
\hline \multicolumn{7}{|l|}{ Emigration } \\
\hline $1867-$ & $\begin{array}{l}.0315^{* *} \\
(.0131)\end{array}$ & $\begin{array}{c}-.2978 * * \\
(.1275)\end{array}$ & $\begin{array}{c}.4033 \\
(.3069)\end{array}$ & $\begin{array}{l}.1627 * * \\
(.0681)\end{array}$ & $\begin{array}{l}.2440 * * * \\
(.0696)\end{array}$ & $\begin{array}{l}.2911 * * \\
(.1213)\end{array}$ \\
\hline $\begin{array}{l}\text { County fixed } \\
\text { effects }\end{array}$ & Yes & Yes & Yes & Yes & Yes & Yes \\
\hline Controls & Yes & Yes & Yes & Yes & Yes & Yes \\
\hline $\begin{array}{l}\text { Shocks } \times \text { market } \\
\text { access }\end{array}$ & Yes & Yes & Yes & Yes & Yes & Yes \\
\hline Observations & 2,070 & 2,341 & 2,341 & 2,359 & 2,339 & 2,339 \\
\hline$F$-statistic & 24.37 & 21.49 & 21.49 & 20.56 & 21.46 & 21.46 \\
\hline $\begin{array}{l}\text { Mean depen- } \\
\text { dent variable }\end{array}$ & .06 & 5.30 & 4.17 & .21 & .09 & .11 \\
\hline
\end{tabular}

Note.-Horses per area is the number of horses per area in 1910. Farm workers and industrial workers are measured in logs in 1910. Any firm is an indicator variable equal to one if there is a corporation in 1900-1920. Labor organization per industrial worker and strikers per industrial worker are the number of labor movement and strike participants per industrial worker in 1910, respectively. The excluded instrument is the interaction between the number of growing season frost shocks $1864-67$ and proximity to the nearest emigration port. Proximity is defined as minus the log of distance. All regressions include county fixed effects and control for the log of the population at the baseline. Additional control variables are growing season frost shocks $1864-67$, proximity to the nearest emigration port, nearest town, nearest trade port, nearest weather station, and Stockholm, log area, latitude, longitude, as well as an urban indicator and a set of indicators for high soil quality for the production of barley, oats, wheat, dairy, and timber. Shocks $\times$ market access includes the interaction between growing season frost shocks and proximity to the nearest town and trade port, respectively. The $F$-statistic refers to the excluded instrument. Standard errors (in parentheses) are clustered at the weather station level.

$$
\begin{aligned}
& * p<.1 . \\
& * * p<.05 . \\
& * * * p<.01 .
\end{aligned}
$$

tion, we find that such municipalities have a greater presence of corporations, as measured using data on the universe of Swedish corporations during 1900-1920 (col. 4). Finally, we find evidence of substitution from labor to capital in agriculture, as witnessed by increased adoption of draft horses, which was a laborsaving technology (col. 1). ${ }^{61}$ Together with a decreased agricultural workforce, this is indicative of higher capital/labor ratios in agriculture. Rising outside options are consistent with these findings, as they allow workers to bargain more effectively for higher wages, especially when they are organized in unions.

${ }^{61}$ The new laborsaving threshing machines used draft horses, in contrast to the older labor-intensive equipment, which instead predominantly used oxen as draft animals (Sjöström 1922; Morell 2001) 
As the labor unions that we observe in our data were almost exclusively organized in nonagricultural sectors, the shift toward industrial employment that we observe could potentially explain the rise in labor movement membership in a mechanical way. To test for this possibility, we use employment data from the 1910 census and rerun regressions for the effect of emigration on the labor movement and strike participation expressed per industrial worker rather than per capita. This specification will net out any changes in the sectoral composition of employment. ${ }^{62}$ Columns 5 and 6 of table 10 show the results of this test. Both variables are positive and significant, indicating that the main conclusions are robust to this variation. Hence, holding the number of industrial workers constant, labor organization in 1910 and strike participation in 1909 were still more intense in high-emigration areas. ${ }^{63}$

Remittances sent home by emigrants may also increase resources per capita. Unfortunately, the lack of disaggregated data precludes an empirical analysis of the extent of monetary remittances sent back to Sweden. As a share of GDP, aggregate remittances to Sweden were, however, smaller than for Ireland and were "almost insignificant" in comparison to Italy (Babcock 1914). As a different comparison, remittances to Sweden were below levels sent to low-income countries today, since they amounted to below 1 percent of GDP while they are above 4 percent of GDP for current less developed countries. Moreover, it is not known how much of the money sent as remittances was used by stayers to buy tickets and emigrate themselves.

\section{Selection into Migration}

Selection effects are a first-order concern when studying migration. If those who choose to emigrate are different from those who stay behind, migration may change the composition of the origin community population over time. This could itself have direct effects on our outcomes of interest. Since selection does not imply any changes in individual behavior, it is important to assess its importance. Whereas table 10 already showed that labor movement membership was not driven by agricultureskewed emigration, here we consider several additional selection channels.

Research on Norwegian migrants during the Age of Mass Migration has found that migrant self-selection in terms of earnings potential was nega-

${ }^{62}$ Even though we cannot rule out that there is a nonlinear relationship between industrial workers and the share of them who are unionized, the correlation suggests that the relationship is in fact linear as evidenced in fig. A.4.

${ }^{63}$ Even though the instrument affects the agricultural sector more strongly, the majority of citizens worked within agriculture prior to the first wave of mass emigration. Owing to the high level of mobility across sectors in local labor markets (Heckscher 1941), the later growth of the industrial sector was likely to draw on local agricultural workers. The instrument therefore increases migrant networks in more sectors than agriculture. 
tive from urban areas but ambiguous from rural areas (Abramitzky, Boustan, and Eriksson 2012). To the extent that Swedish and Norwegian migration had similar types of selection, this should not substantially affect our results, given that most of the variation used in this study comes from rural areas. This is verified by reestimating our models on labor movement participation using the rural sample alone. Table B.2 shows that our findings on labor movement membership, striking, and voting are robust to the exclusion of urban areas. ${ }^{64}$ All point estimates remain significant and roughly similar, with two of them being higher and two being lower than the main estimates.

Data on the share of eligible voters allow us to test for a certain type of selection effect, which could explain our results in a more direct way. For example, McKenzie and Rapoport (2010) show that stronger migrant networks may lead to negative selection of migrants. Given that voting eligibility was based on economic status and gender, it can serve as an indicator of changes to the composition of the population that has direct bearing on electoral outcomes. However, column 5 of table 6 indicates that emigration had no significant effect on the share of eligible voters. The sign of the estimated changes goes from positive when excluding controls to negative when they are included. As a result, the effects on voting patterns do not appear to be explained by this form of selection.

Selection may also be active along other dimensions than income or voting eligibility. Using 1890 census data, table 8 shows tests for a range of demographic differences across high- and low-emigration municipalities. Column 4 shows that there is no difference in the number of people born in a different municipality, indicating that welfare migration and selective in-migration of more leftist individuals should not explain our results. Moreover, we find no effect on the prevalence of unmarried adults nor on the ratio of women to men. As these estimates are small compared to their mean, low power should not be the reason for failing to reject the null hypothesis. In addition, column 8 shows that emigration leads to a lower average age. Potentially, this effect is driven by increased fertility, but the effect is fairly small and significant only at the 10 percent confidence level. ${ }^{65}$

Finally, we consider the possibility that emigrants were ideologically selected. If more right-leaning individuals chose to emigrate, for example, because of the pull factors of more freedom or because of more risk-taking or entrepreneurial preferences, the pool of voters would mechanically change in favor of the left. Similarly, emigrants may have been those who

\footnotetext{
${ }^{64}$ Note that regressions on welfare expenditures and representative democracy are already restricted to the rural sample.

${ }_{65}$ Table C. 18 shows the effect of emigration on age at the mean as well as the $25 \mathrm{th}, 50 \mathrm{th}$, and 75 th percentiles.
} 
were less inclined to join labor unions. ${ }^{66}$ To deal with this concern, we perform a simple bounding exercise. We count the total number of emigrants since 1867 and consider different scenarios for the fraction of them that would not have been labor movement members or left-wing voters. Table B.3 displays the sensitivity of our estimates concerning the labor movement and the vote share of the left when assuming that 75 or 100 percent of the emigrants would have been against them if they had stayed in Sweden. ${ }^{67}$ As expected, the point estimates become smaller as we assume a more skewed ideological selection, reducing the baseline result by about half in the case of the vote share of the left. Nevertheless, the results remain statistically significant. This indicates that such selection cannot explain the entire effect of emigration on left-wing voting.

\section{Exposure to American Attitudes}

Existing studies linking migration and political outcomes have emphasized the potential of host country attitudes being transmitted to origin countries, thereby affecting the political outcomes. This raises the question of whether American attitudes could have inspired the Swedish labor movement, whether it be via return migration or information transmission through networks. A priori, there is little evidence of the Swedish labor movement being influenced by the United States, however, while the effect of Scandinavian labor organizers on American unions is well documented (Nordahl 1994; Bengston and Brook 1999). We provide an indirect test of the possibility of US influence by estimating the impact of emigration on two other voluntary associations that we observe in the data: nonstate free churches and temperance lodges. Both types of organizations had strong influences in the United States. Methodists were common among the free churches, and the temperance movement largely consisted of Swedish chapters of an American organization, the International Order of Good Templars. Together with the labor movement, these organizations constituted the three "popular movements" of the era, marked by rapidly growing membership numbers and by the use of democratic processes in an era when Sweden was yet undemocratic.

Table 11 displays our results for per capita membership in both types of organizations. Similarly to the specification for the labor movement, we consider the average membership between 1900 and 1920. If there were transmission of information or attitudes to Swedes through their overseas networks, one would expect to see an increased participation in these types

\footnotetext{
${ }^{66}$ Historical evidence of Swedish emigrants contributing to US labor unions speaks against this possibility to some extent (Nordahl 1994; Bengston and Brook 1999).

${ }_{67}$ For the labor movement, we consider only the latter case, since counting 25 percent of the emigrants as members would inflate the membership rates.
} 
TABLE 11

Membership in Nonlabor Organizations

\begin{tabular}{|c|c|c|c|c|c|c|}
\hline & \multicolumn{3}{|c|}{ OLS } & \multicolumn{3}{|c|}{ IV } \\
\hline & (1) & (2) & (3) & $(4)$ & $(5)$ & $(6)$ \\
\hline & \multicolumn{6}{|c|}{ Dependent Variable: Free Church Members } \\
\hline Emigration $1867-1900$ & $\begin{array}{l}.0063^{* * * *} \\
(.0011)\end{array}$ & $\begin{array}{l}.0054^{* * *} \\
(.0012)\end{array}$ & $\begin{array}{l}.0054 * * * \\
(.0012)\end{array}$ & $\begin{array}{c}-.0081 \\
(.0097)\end{array}$ & $\begin{array}{c}-.0036 \\
(.0090)\end{array}$ & $\begin{array}{r}-.0037 \\
(.0087)\end{array}$ \\
\hline Observations & 2,358 & 2,358 & 2,358 & 2,358 & 2,358 & 2,358 \\
\hline$F$-statistic & & & & 13.11 & 17.30 & 17.19 \\
\hline \multirow[t]{2}{*}{ Mean dependent variable } & .01 & .01 & .01 & .01 & .01 & .01 \\
\hline & \multicolumn{6}{|c|}{ Dependent Variable: Temperance Members } \\
\hline Emigration $1867-1900$ & $\begin{array}{l}.0077 * * * \\
(.0016)\end{array}$ & $\begin{array}{l}.0068^{* * * *} \\
(.0015)\end{array}$ & $\begin{array}{l}.0068 * * * \\
(.0015)\end{array}$ & $\begin{array}{c}-.0374 * * \\
(.0160)\end{array}$ & $\begin{array}{r}-.0274 * \\
(.0162)\end{array}$ & $\begin{array}{r}-.0265 \\
(.0165)\end{array}$ \\
\hline County fixed effects & Yes & Yes & Yes & Yes & Yes & Yes \\
\hline Controls & No & Yes & Yes & No & Yes & Yes \\
\hline Shocks $\times$ market access & No & No & Yes & No & No & Yes \\
\hline Observations & 2,358 & 2,358 & 2,358 & 2,358 & 2,358 & 2,358 \\
\hline$F$-statistic & & & & 13.11 & 17.30 & 17.19 \\
\hline Mean dependent variable & .04 & .04 & .04 & .04 & .04 & .04 \\
\hline
\end{tabular}

Note.-This table displays the effects of log emigration 1867-1900 on average per capita membership in nonlabor organizations 1900-1920. The excluded instrument is the interaction between the number of growing season frost shocks $1864-67$ and proximity to the nearest emigration port. Proximity is defined as minus the log of distance. All regressions include county fixed effects and control for the log of the population at baseline. Additional control variables are growing season frost shocks $1864-67$, proximity to the nearest emigration port, nearest town, nearest trade port, nearest weather station, and Stockholm, $\log$ area, latitude, longitude, as well as an urban indicator and a set of indicators for high soil quality for the production of barley, oats, wheat, dairy, and timber. Shocks $\times$ market access includes the interaction between growing season frost shocks and proximity to the nearest town and trade port, respectively. The $F$-statistic refers to the excluded instrument. Standard errors (in parentheses) are clustered at the weather station level.

$* p<.1$.

$* * p<.05$

$* * * \quad p<.01$.

of organizations. The IV results in table 11 show no significant positive effects, however. Membership in both free churches and temperance lodges displays negative and insignificant coefficient estimates. These results do not rule out that the labor movement was in some way influenced by the United States, but they nevertheless suggest that general cultural transmission through migrants was not a major factor.

Finally, if emigration areas have more networks in other parts of Sweden that have more experience with the labor movement, internal political remittances could also be a potential mechanism. Given that the labor movement had a substantially larger presence especially in urban areas, the fact that our positive estimated impact on labor movement membership goes along with less urbanization-as shown in column 2 of table 8 is an indication that internal political remittances are not likely to play a role in explaining this result. 
OOO

\section{Placebo and Robustness Tests}

The available time-series data suggest a natural placebo test for our identification assumption. We rely on frost shocks occurring only in the 186467 period, which draws support from historians who have found that later harvest outcomes did not cause further emigration (Thomas 1941). We therefore treat frost shocks during all other 4-year periods from 1859 to 1900 as placebos and examine the effect of these placebo shocks interacted with port proximity on all our outcomes, including emigration. Shocks in 1864-69 are excluded to avoid the treatment period.

As the variation in frost shocks is random, placebo estimates are expected to be distributed around zero. We should therefore expect coefficients associated with the treatment period to be in the extremes of the distribution. To make frost shocks comparable across periods with very few or very many shocks and avoid the influence of outliers, they are categorized in quintiles of the shock distribution over the period. Figure 10 displays probability density functions of all placebo point estimates for emigration and labor organization rates as outcomes. ${ }^{68}$ Black bars represent the reduced-form effect associated with the treatment period (186467 ), while white bars represent placebo periods. As expected, placebo estimates are scattered across a range of values while the treatment coefficients are consistently at the ends of the distribution for all outcomes. This indicates that there are no systematic effects at the municipality that consistently give rise to similar effects, but that the shocks occurring in our treatment period were exogenous and unique.

Our identification strategy relies on the exclusion restriction assumption that the instrument has no effect on our outcomes through any variable other than emigration. In particular, it assumes that frost shocks do not have different impacts depending on the proximity to emigration ports. This assumption is supported by the finding that including market access measures interacted with frost shocks has minor effects on our main outcomes as shown in table B.13. While the interaction of shocks with town proximity is insignificant, the interaction with trade port proximity is significantly negative for three out of eight outcomes, including labor organization. This suggests that locations that are more connected, in terms of being closer to trade ports, are less affected by frost shocks. The fact that the market access effect is negative indicates that, to the extent that our instrument picks up such variation, the exclusion restriction would be violated in a way that would bias our estimates toward zero. This is also supported by the tendency of our IV estimates to become slightly larger when we control for the market access interactions.

\footnotetext{
${ }^{68}$ Figure B.1 displays placebo point estimates in terms of all other outcome variables.
} 

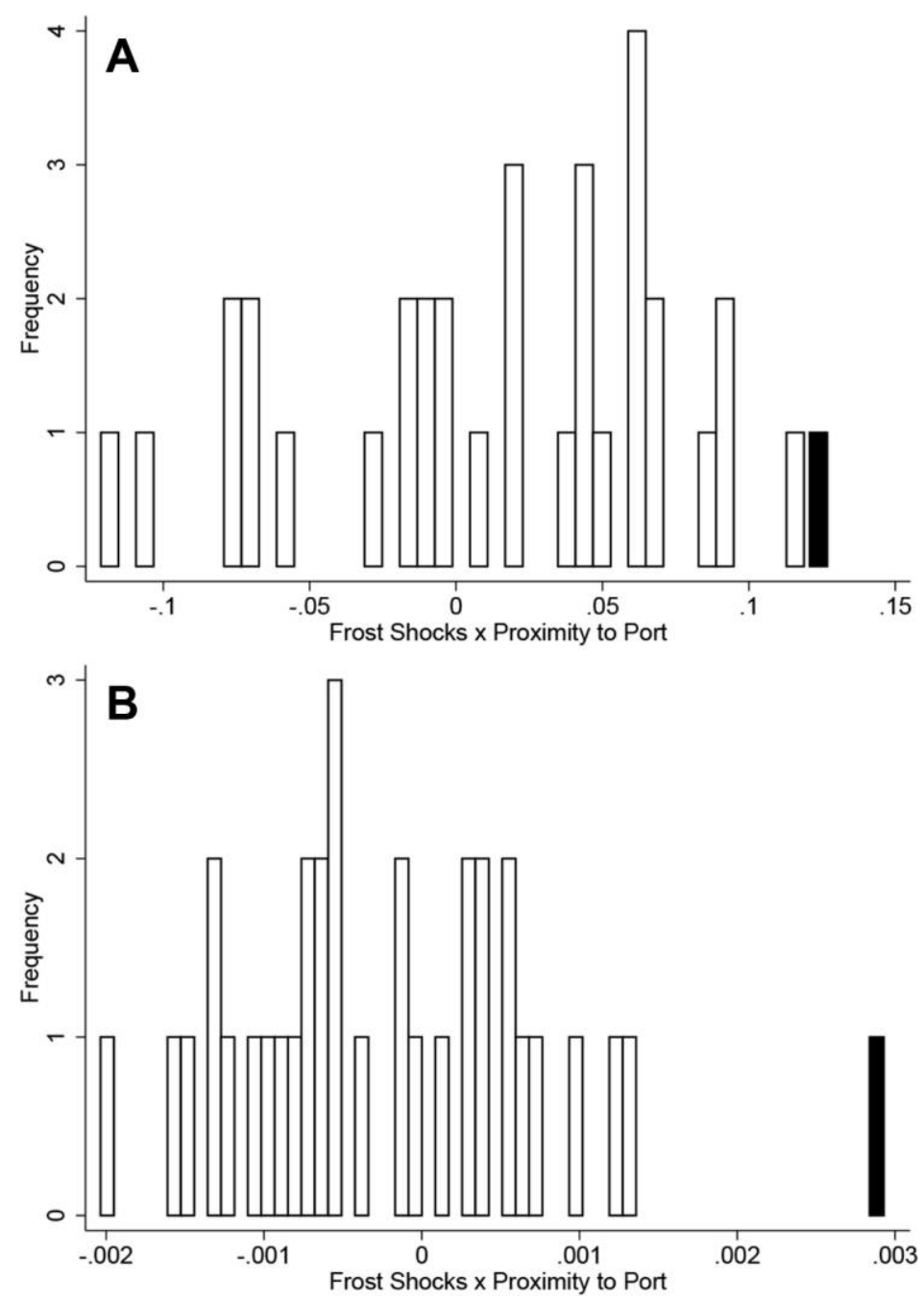

Fig. 10.-Treatment and placebo shocks, 1859-1900. A, Emigration, 1867-1920. B, Labor organization, 1900-1920. Frequency distributions of reduced-form coefficients from regressing the outcome variables on the interaction between growing season frost shocks and proximity to emigration port during all consecutive 4-year periods between 1859 and 1900. Proximity is defined as minus the log of distance. The coefficient associated with the treatment period of 1864-67 is highlighted in black. Frost shocks are categorized into quintiles of the distribution before interacting with port proximity. All regressions include county fixed effects and control for the log of the population at baseline. All regressions control for growing season frost shocks in the relevant 4-year period, proximity to the nearest emigration port, nearest town, nearest trade port, nearest weather station, and Stockholm, log area, latitude, longitude, as well as an urban indicator and a set of indicators for high soil quality for the production of barley, oats, wheat, dairy, and timber. Regressions also include the interaction between growing season frost shocks and proximity to the nearest town and trade port, respectively. 
We also test the robustness of these results to selecting a subset of only the larger trade ports and towns to create our measures of market access. To the extent that the larger economic hubs provide a better measure of market access, this may be a stricter test of our identifying assumptions. Table B.15 displays the effect of controlling for frost shocks interacted with the five largest trade ports and the 10 largest towns, respectively ${ }^{69}$ Reassuringly, the results are very robust to these modifications, indicating that the exclusion restriction assumption is unlikely to be violated because of frost shocks having heterogeneous impacts by port proximity. Formal tests for the null hypothesis that the coefficient estimates for the instrument are equal to those of the market access interaction terms are uniformly rejected. Furthermore, table B.16 replaces the market access measures with pre-emigration measures of economic development: land value and agricultural yield in 1810. Interacting these variables with frost shocks in 1864-67 provides a different way of controlling for the potentially heterogeneous effects of frost shocks by emigration port proximity. Again, our results are robust to this variation.

While the above results indicate no clear violations of the exclusion restriction, we can examine the sensitivity of our results to directly imposing such violations using the method of Conley et al. (2012). Following common practice, we calculate what is the largest exclusion restriction violation that can be assumed and still yield a significant positive effect on the labor organization rate in 1900-1920. We find that the effect of emigration remains significant at the 95 percent level when at most 52 percent of the reduced-form effect of the instrument on labor organization can be attributed to a direct effect of the instrument itself. Our cutoff is increased to 75 percent of the instrument's reduced-form effect if we instead test a summary index consisting of the average $Z$-score of all our outcome variables. The sensitivity analysis indicates that our results are robust even under substantial violations of the exclusion restriction assumption.

Different cutoffs for defining frost shocks are examined in table B.5. Panel A displays the reduced-form estimates of our main outcome variables using shocks defined at the baseline of one standard deviation, while panels B and C display estimates from letting shocks count at a 0.75 or 1.25 threshold. In panel $\mathrm{D}$, we define growing season using months with a mean temperature of above $5^{\circ} \mathrm{C}$, as this is the upper bound for counting a month as being in the growing season following the recommendations of the Swedish Meteorological and Hydrological Institute. The baseline case uses $3^{\circ} \mathrm{C}$. The signs, magnitudes, and statistical significance of these results are similar to the main results.

We next evaluate the robustness of our analysis to large (absolute) values of our key variables. In particular, we want to control for the possibility of certain locations that are very distant from ports driving our results.

${ }^{69}$ Table B.14 displays the reduced-form counterpart of the same test. 
For this purpose, we censor variables at the 5 th and 95 th percentiles, assigning observations outside of that interval the variable value at the nearest bound. This compresses the range of values that variables take on and reduces the potential for a small number of observations with extreme values to affect estimates. We also display the results after further tightening the variable distributions, by censoring at the 10th and 90th percentiles. Panels A and B of table B.6 do this for two variables: growing season frost shocks in 1864-67 and proximity to the nearest emigration port. The resulting variables are then used to redefine the instrument, that is, the interaction between shocks and port proximity. All results are robust to this change. Panels $\mathrm{C}$ and $\mathrm{D}$ then extend this procedure to all nonbinary variables that are included in our models. Our results are robust to this modification as well. In addition, table B.7 documents that our main results are robust to dropping all municipalities above the 90 th percentile of distance to emigration ports. Thus, distant northern municipalities have a limited influence on our results.

To test for the robustness of the statistical inference, table B.9 provides estimates of the reduced-form regressions using three different types of standard errors. In panel A, we cluster standard errors at the county level rather than at the weather station, as political organization and policy may be more correlated within counties, which are established political boundaries. Panels B and C instead estimate spatial-correlation robust standard errors, which allow linearly declining correlations across municipalities of up to 100 or 200 kilometers, using the method of Conley (1999). This method has the advantage of not relying on a fixed number of clusters and allows residuals to be correlated within a given radius of each unit of observation. Panel D generates standard errors using the wild cluster- $t$ bootstrap method, which may improve tests when there are few clusters (Cameron, Gelbach, and Miller 2008). The estimates in panels A-D display the same pattern as our main regressions, with few changes to significance levels. The estimates on transitioning to representative democracy lose precision with the wild cluster- $t$ bootstrap method but are nevertheless robust to both levels of spatial dependence using Conley-type standard errors.

The linear relationship apparent in the nonparametric estimations in figures 8 and 9 suggest that a linear specification of the instrument is a good approximation. Nevertheless, table B.10 documents that our results are robust to specifying the frost shocks in logs instead of levels and port proximity in levels instead of logs. We also verify the robustness of our results to using logs of our main outcome variables rather than per capita values. Table B.12 displays our results for labor organizations and welfare spending. ${ }^{70}$

${ }^{70}$ To avoid putting high weight on near-zero values on welfare spending, we use the transformation $\log$ (spending +100 ), where SEK 100 is less than the 1st percentile value of the distribution. Without this transformation, the results are weaker, with $p$-values of .124 and .014 in 1918 and 1919, respectively. 
In table B.17, we fix two periods, either 1867-79 (only the first wave) or 1867-1900 (when our first main outcome variable begins). Estimates are stable across specifications. However, estimates in panel A using only first-wave emigration have weaker $F$-statistics and less precisely estimated second-stage coefficients. The reason is that emigration patterns become stronger over time as chain migration continues, increasing the strength of our instrument.

Appendix C displays full IV regression output for all main outcome variables, including OLS, reduced-form, first-stage, and second-stage results. It also reports the placebo first stage using nongrowing season shocks with and without controls.

\section{Conclusion}

During the Age of Mass Migration, 30 million Europeans left their home countries for the United States. Among them were more than 1 million Swedish citizens, making Sweden one of the major origin countries in per capita terms. This paper uses detailed Swedish data from the period 18601920 to shed some light on the question of whether large-scale emigration can lead to political development in undemocratic origin countries. Our results indicate that it may indeed be the case. Using an instrument based on travel costs and the severe agricultural shocks that sparked the initial wave of migration to the United States, we predict total emigration flows over 50 years. We show that emigration caused significantly higher rates of labor organization, strike participation, voter turnout, and left-wing voting in the long run. The findings are consistent with the hypothesis that the improved outside options generated by migrant networks bolstered potential labor activists, who faced repression from local elites for organizing. Since the labor movement had strong ties to the political left, our findings on turnout and political party preferences are likely driven by that mechanism.

Emigration also led to formal political change. Welfare expenditures per capita rose in high-emigration municipalities, as did the likelihood of adopting more inclusive institutions by transitioning from direct to representative democracy. These results are consistent with the mechanism proposed by Acemoglu and Robinson (2000, 2006), in which elites implement institutional change in order to commit to better outcomes for citizens.

Overall, the Age of Mass Migration improved connected citizens' outside options and brought positive effects on support for redistribution and actual redistribution during a time when Sweden was still undemocratic. Migration arguably played a role in the country's transition to a full democracy in the early twentieth century. 
How externally valid are the results presented in this study? For example, do our findings generalize to other countries that had high emigration rates during the Age of Mass Migration? Figure 1, discussed in the introduction, documents that there is a positive correlation between historical emigration from $29 \mathrm{OECD}$ countries and contemporary trade union density. Extrapolating from our main setting to a cross-country analysis with a small number of observations would certainly be very speculative. Nevertheless, the robust correlation raises the possibility that the free immigration policy maintained by the United States in the nineteenth century and until World War I may have had significant unintended consequences for political development in the rest of the world.

Another question is whether our findings have any bearing on current emigration waves and record global refugee stocks. The mechanism that we propose, that improved outside options may encourage risky activism, is general and potentially applies to many other settings, including contemporary ones. However, the question of how responsive political elites will be to such activism is less straightforward. Agricultural and early industrial economies, such as Sweden in our period of study, are heavily reliant on labor for production. This may explain the urgent political response of Swedish elites as emigration took on greater proportions. In modern autocracies, where leaders often rely on natural resource rents, the economic incentive for elites to respond to popular movements may be lower. Nevertheless, to the extent that activists are able to reach a significant mass, institutional change may occur as economies experience critical junctures, consistent with Acemoglu and Robinson (2006).

\section{References}

Abramitzky, R., and L. P. Boustan. 2017. "Immigration in American Economic History." L. Econ. Literature 55 (4): 1311-45.

Abramitzky, R., L. P. Boustan, and K. Eriksson. 2012. "Europe's Tired, Poor, Huddled Masses: Self-Selection and Economic Outcomes in the Age of Mass Migration." A.E.R. 102 (5): 1832-56.

Acemoglu, D., S. Johnson, and J. Robinson. 2005. "The Rise of Europe: Atlantic Trade, Institutional Change, and Economic Growth." A.E.R. 95 (3): 546-79.

Acemoglu, D., and J. A. Robinson. 2000. "Why Did the West Extend the Franchise? Democracy, Inequality, and Growth in Historical Perspective." O. I.E. 115:116799.

. 2006. Economic Origins of Dictatorship and Democracy. Cambridge: Cambridge Univ. Press.

Ager, P., C. Worm Hansen, and P. Sandholt Jensen. 2017. "Fertility and Early-Life Mortality: Evidence from Smallpox Vaccination in Sweden.” LEuropean Econ. Assoc. 16 (2): 487-521.

Ahmed, F. Z. 2012. "The Perils of Unearned Foreign Income: Aid, Remittances, and Government Survival." American Polit. Sci. Rev. 106 (1): 146-65.

. 2013. "Remittances Deteriorate Governance." Reu. Econ. and Statis. 95 (4): 1166-82. 
OOO

Alford, J. R., C. L. Funk, and J. R. Hibbing. 2005. "Are Political Orientations Genetically Transmitted?” American Polit. Sci. Rev. 99 (2): 153-67.

Andersson, D., M. Karadja, and E. Prawitz. 2017. "Mass Migration, Cheap Labor, and Innovation.” Manuscript, Inst. Internat. Econ. Studies, Stockholm Univ.

Anelli, M., and G. Peri. 2017. "Does Emigration Delay Political Change? Evidence from Italy during the Great Recession." Econ. Policy 32 (91): 551-96.

Babcock, K. C. 1914. The Scandinavian Element in the United States. Studies in the Social Sciences, vol. 3. Urbana: Univ. Illinois.

Barsbai, T., H. Rapoport, A. Steinmayr, and C. Trebesch. 2017. "The Effect of Labor Migration on the Diffusion of Democracy: Evidence from a Former Soviet Republic." American Econ. I.: Appl. Econ. 9 (3): 36-69.

Barton, H. A. 1994. A Folk Divided: Homeland Swedes and Swedish Americans, 18401940. Carbondale: Southern Illinois Univ. Press.

Batista, C., and P. C. Vicente. 2011. "Do Migrants Improve Governance at Home? Evidence from a Voting Experiment." World Bank Econ. Rev. 25 (1): 77-104.

Beijbom, U. 1995. Mot löftets land: Den svenska utvandringen. Stockholm: LT.

Beine, M., and K. Sekkat. 2013. "Skilled Migration and the Transfer of Institutional Norms." IZA J. Migration 2 (1): art. 9.

Bengston, H., and M. Brook. 1999. On the Left in America: Memoirs of the ScandinavianAmerican Labor Movement. Carbondale: Southern Illinois Univ. Press.

Bohlin, J., and A.-M. Eurenius. 2010. "Why They Moved-Emigration from the Swedish Countryside to the United States, 1881-1910.” Explorations Econ. Hist. 47 (4): 533-51.

Boix, C. 2003. Democracy and Redistribution. Cambridge: Cambridge Univ. Press.

Booth, A. L., and M. Chatterji. 1995. "Union Membership and Wage Bargaining When Membership Is Not Compulsory." Econ.I. 105 (429): 345-60.

Brattne, B., and S. Akerman. 1976. "The Importance of the Transport Sector for Mass Emigration." In From Sweden to America: A History of the Migration, edited by H. Runblom and H. Norman, 176-200. Uppsala: Univ. Uppsala Press.

Bryan, G., S. Chowdhury, and A. M. Mobarak. 2014. "Underinvestment in a Profitable Technology: The Case of Seasonal Migration in Bangladesh." Econometrica 82 (5): 1671-1748.

Budd, J. W., and I.-G. Na. 2000. "The Union Membership Wage Premium for Employees Covered by Collective Bargaining Agreements." L. Labor Econ. 18 (4): 783-807.

Cameron, A. C., J. B. Gelbach, and D. L. Miller. 2008. "Bootstrap-Based Improvements for Inference with Clustered Errors." Rev. Econ. and Statis. 90 (3): 414-27.

Chauvet, L., and M. Mercier. 2014. "Do Return Migrants Transfer Political Norms to Their Origin Country? Evidence from Mali." L. Comparative Econ. 42 (3): 630-51.

Clemensson, P. 1996. "Göteborgska källor till den stora utvandringen.” Dokumentet no. 3, Landsarkivet i Göteborg.

Conley, T. G. 1999. “GMM Estimation with Cross Sectional Dependence.” L.Econometrics 92 (1): 1-45.

Conley, T. G., C. B. Hansen, and P. E. Rossi. 2012. "Plausibly Exogenous." Rev. Econ. and Statis. 94 (1): 260-72.

Dell, M., B. F. Jones, and B. A. Olken. 2014. "What Do We Learn from the Weather? The New Climate-Economy Literature.” L. Econ. Literature 52 (3): 740-98.

Dippel, C., A. Greif, and D. Trefler. 2015. "The Rents from Trade and Coercive Institutions: Removing the Sugar Coating." Working Paper no. 20958, NBER, Cambridge, MA. 
Docquier, F., E. Lodigiani, H. Rapoport, and M. Schiff. 2016. "Emigration and Democracy." L. Development Econ. 120:209-23.

Docquier, F., and H. Rapoport. 2003. "Ethnic Discrimination and the Migration of Skilled Labor." L. Development Econ. 70 (1): 159-72.

Edvinsson, R. 2005. "Growth, Accumulation, Crisis: With New Macroeconomic Data for Sweden 1800-2000." PhD thesis, Dept. Econ. Hist., Stockholm Univ.

- 2013. "New Annual Estimates of Swedish GDP, 1800-2010." Econ. Hist. Rev. 66 (4): 1101-26.

Enflo, K., C. Lundh, and S. Prado. 2014. "The Role of Migration in Regional Wage Convergence: Evidence from Sweden 1860-1940.” Explorations Econ. Hist. 52:93-110.

Escriba-Folch, A., C. Meseguer, and J. Wright. 2015. "Remittances and Democratization." Internat. Studies O. 59 (3): 571-86.

Giuliano, P., and A. Spilimbergo. 2014. "Growing Up in a Recession." Rev. Econ. Studies 81 (2): 787-817.

Giulietti, C., J. Wahba, and Y. Zenou. 2014. "Strong versus Weak Ties in Migration." IZA Discussion Paper no. 8089, Inst. Labor Econ., Bonn.

Grenholm, G., J. Rosén, S. Carlsson, and J. Cornell. 1985. Den suenska historien: 14, Från storstrejken 1909 till folkhemspolitik. Stockholm: Bonnier.

Habakkuk, H. J. 1962. American and British Technology in the Nineteenth Century: The Search for Labour-Saving Inventions. Cambridge: Cambridge Univ. Press.

Hansen, J., and S. Lebedeff. 1987. "Global Trends of Measured Surface Air Temperature.” J. Geophysical Res.: Atmospheres (1984-2012) 92 (D11): 13345-72.

Harari, M., and E. La Ferrara. 2013. "Conflict, Climate and Cells: A Disaggregated Analysis.” Discussion Paper no. DP9277, Centre Econ. Policy Res., London.

Hatton, T. J. 1995. "A Model of Scandinavian Emigration, 1870-1913.” European Econ. Rev. 39 (3): 557-64.

Hatton, T. J., and J. G. Williamson. 1998. The Age of Mass Migration: Causes and Economic Impact. Oxford: Oxford Univ. Press.

2005. "What Fundamentals Drive World Migration?" In Poverty, International Migration, and Asylum, edited by G. J. Borjas and J. Crisp, 15-38. London: Palgrave Macmillan.

Heckscher, E. F. 1941. Svensk arbete och liv: Från medeltiden till nutiden. Stockholm: Albert Bonniers Förlag.

Hellstenius, J. 1871. "Skördarna i Sverige och deras verkningar.” Statistisk Tidskrift 29:77-119.

Hinnerich, B. T., and P. Pettersson-Lidbom. 2014. "Democracy, Redistribution, and Political Participation: Evidence from Sweden 1919-1938." Econometrica 82 (3): 961-93.

Hirsch, B. T. 2004. "Reconsidering Union Wage Effects: Surveying New Evidence on an Old Topic." L. Labor Res. 25 (2): 233-66.

Hirschman, A. O. 1970. Exit, Voice, and Loyalty: Responses to Decline in Firms, Organizations, and States. Cambridge, MA: Harvard Univ. Press.

- 1978. "Exit, Voice, and the State." World Politics 31 (1): 90-107.

Holmlund, B., and P. Lundborg. 1999. "Wage Bargaining, Union Membership, and the Organization of Unemployment Insurance." Labour Econ. 6 (3): 397-415.

Hovde, B. J. 1934. "Notes on the Effects of Emigration upon Scandinavia." L. Modern Hist. 6 (3): 253-79.

Hvidt, K. 1975. Flight to America: The Social Background of 300,000 Danish Emigrants. New York: Academic Press.

Jantunen, J., and K. Ruosteenoja. 2000. "Weather Conditions in Northern Europe in the Exceptionally Cold Spring Season of the Famine Year 1867." Geophysica 36 (1-2): 69-84. 
OOO

Jennings, M. K., L. Stoker, and J. Bowers. 2009. "Politics across Generations: Family Transmission Reexamined." L. Politics 71 (3): 782-99.

Jörberg, L. 1972. A History of Prices in Sweden, 1732-1914. Lund: Gleerup.

Jungenfelt, K. 1959. "Lönernas andel av nationalinkomsten: En studie över vissa sidor av inkomstfördelningens utveckling i Sverige.” Manuscript, Dept. Econ., Uppsala Univ.

Kälvemark, A.-S. 1972. "Reaktionen mot utvandringen: Emigrationsfrågan i svensk debatt och politik 1901-1904." PhD diss., Uppsala Univ.

Kapur, D. 2014. "Political Effects of International Migration." Ann. Rev. Polit. Sci. $17: 479-502$.

Kapur, D., and J. McHale. 2005. Give Us Your Best and Brightest: The Global Hunt for Talent and Its Impact on the Developing World. Washington, DC: Center Global Development.

Kim, S. E., and Y. Margalit. 2016. "Informed Preferences? The Impact of Unions on Workers' Policy Views.” American I. Polit. Sci. 61 (3): 728-43.

Kommerskollegii. 1909. Arbetsinställelser under åren 1903-1907. E:1. Stockholm: Kungliga Kommerskollegii Afdelning för arbetsstatistik.

— 1910. Redogörelse för Lockouterna och Storstrejken i Sverige år 1909 III. Stockholm: Kungliga Kommerskollegii Afdelning för arbetsstatistik.

Li, X., J. McHale, and X. Zhou. 2017. "Does Brain Drain Lead to Institutional Gain?” World Economy 40 (7): 1454-72.

Lindbeck, A., and D. J. Snower. 1986. "Wage Setting, Unemployment, and InsiderOutsider Relations." A.E.R. 76 (2): 235-39.

Ljungberg, J. 1997. "The Impact of the Great Emigration on the Swedish Economy." Scandinavian Econ. Hist. Rev. 45 (2): 159-89.

Lundkvist, S. 1977. Folkrörelserna i det svenska samhället, 1850-1920. Uppsala: Acta Universitatis Upsaliensis.

Madestam, A., and D. Yanagizawa-Drott. 2012. "Shaping the Nation: The Effect of Fourth of July on Political Preferences and Behavior in the United States." Manuscript, Harvard Univ.

Margo, R. A. 1991. "Segregated Schools and the Mobility Hypothesis: A Model of Local Government Discrimination." O. I.E. 106 (1): 61-73.

Mariani, F. 2007. "Migration as an Antidote to Rent-Seeking?" L. Development Econ. 84 (2): 609-30.

Massey, D. S., J. Arango, G. Hugo, A. Kouaouci, A. Pellegrino, and J. E. Taylor. 1993. "Theories of International Migration: A Review and Appraisal." Population and Development Rev. 19 (3): 431-66.

McKenzie, D., and H. Rapoport. 2007. "Network Effects and the Dynamics of Migration and Inequality: Theory and Evidence from Mexico." I. Development Econ. 84 (1): 1-24.

- 2010. "Self-Selection Patterns in Mexico-U.S. Migration: The Role of Migration Networks." Rev. Econ. and Statis. 92 (4): 811-21.

Mercier, M. 2016. "The Return of the Prodigy Son: Do Return Migrants Make Better Leaders?" I. Develobment Econ. 122:76-91.

Morell, M. 2001. Det svenska jordbrukets historia. Bd 4, Jordbruket $i$ industrisamhället: 1870-1945. Stockholm: Natur och kultur/LT i samarbete med Nordiska museet och Stift. Lagersberg.

Morten, M., and J. Oliveira. 2018. "Migration, Roads and Labor Market Integration: Evidence from a Planned Capital City." Working Paper no. 22158, NBER, Cambridge, MA.

Moses, J. W. 2011. Emigration and Political Development. Cambridge: Cambridge Univ. Press. 
Myrdal, G. 1944. An American Dilemma. Vol. 2: The Negro Problem and Modern Democracy. New York: Harper \& Brothers.

Nelson, H. 1909. Emigrationsutredningen. Bil. 8, Bygdeundersökningar, 6, Öland. Stockholm: Fritze.

Nilsson, G. B. 1964. "Folkval och fyrkval 1863-1909: Två rösträttssystem i teori och praktik." Scandia: Tidskrift för Historisk Forskning 30 (1): 89-137.

Nordahl, P. 1994. "Weaving the Ethnic Fabric: Social Networks among SwedishAmerican Radicals in Chicago 1890-1940." PhD thesis, Umeå Univ.

O'Rourke, K. H. 1997. “The European Grain Invasion, 1870-1913.” L. Econ. Hist. 57 (4): 775-801.

O'Rourke, K. H., and J. G. Williamson. 1995. "Open Economy Forces and Late Nineteenth Century Swedish Catch-Up: A Quantitative Accounting." Scandinavian Econ. Hist. Rev. 43 (2): 171-203.

Östberg, K. 1995. "Att institutionalisera demokratin: Socialdemokratin och kommunalpolitiken under mellankrigstiden." Arkiv för Studier $i$ Arbetarrörelsens Historia (63/64): 1-32.

Palm, L. A. 2000. Folkmängden i Sveriges socknar och kommuner 1571-1997: Med särskild hänsyn till perioden 1571-1751. Visby: Nomen Förlag.

Persson, T., and G. Tabellini. 2009. "Democratic Capital: The Nexus of Political and Economic Change." American Econ. I.: Macroeconomics 1 (2): 88-126.

Pettersson-Lidbom, P. 2015. "Midwives and Maternal Mortality: Evidence from a Midwifery Policy Experiment in Sweden in the 19th Century." Manuscript, Dept. Econ., Stockholm Univ.

Pfutze, T. 2012. "Does Migration Promote Democratization? Evidence from the Mexican Transition." L. Comparative Econ. 40 (2): 159-75.

_. 2014. "Clientelism versus Social Learning: The Electoral Effects of International Migration.” Internat. Studies Q. 58 (2): 295-307.

Preotu, V. 2016. "Emigration as a Pacifying Force?" Working Paper no. WPS 16-03-3, Univ. Geneva.

Puga, D., and D. Trefler. 2014. "International Trade and Institutional Change: Medieval Venice's Response to Globalization.” O. I.E. 129 (2): 753-821.

Quigley, J. M. 1972. “An Economic Model of Swedish Emigration.” O. J.E. 86 (1): 111-26.

Rondahl, B. 1985. "Massutvandringen från Ljusne 1906." Oknytt 6 (3-4): 1621.

Runblom, H., and H. Norman. 1976. From Sweden to America: A History of the Migration. Uppsala: Acta Universitatis Upsaliensis.

Sánchez de la Sierra, R. 2017. "On the Origin of States: Stationary Bandits and Taxation in Eastern Congo." Manuscript, Haas School Bus., Univ. California, Berkeley.

Sarsons, H. 2015. "Rainfall and Conflict: A Cautionary Tale." L. Development Econ. 115:62-72.

Schultz, T. P. 1985. "Changing World Prices, Women's Wages, and the Fertility Transition: Sweden, 1860-1910.” J.P.E. 93 (6): 1126-54.

Sjaastad, L. A. 1962. "The Costs and Returns of Human Migration." J.P.E. 70 (5, pt. 2): 80-93.

Sjöström, A. 1922. Huvuddragen av det svenska jordbrukets utveckling 1871-1919. Stockholm: Ministry of Finance, Government of Sweden.

Snyder, R. L., and J. P. Melo-Abreu. 2005. Frost Protection: Fundamentals, Practice and Economics. Environment and Natural Resources Service Series, vol. 10. Rome: Food and Agriculture Org.

Spilimbergo, A. 2009. "Democracy and Foreign Education.” A.E.R. 99:528-43. 
Sundbärg, G., ed. 1913. Emigrationsutredningen: Betänkande. Stockholm: Norstedt \& Söner.

Swedish Meteorological and Hydrological Institute. 2013. "Hungersnödåret 1867Kallaste majmånaden vi känner.” Swedish Meteorological and Hydrological Inst., Norrköping.

Taylor, A. M., and J. G. Williamson. 1997. "Convergence in the Age of Mass Migration." European Rev. Econ. Hist. 1 (1): 27-63.

Tedebrand, L.-G. 1983. "Strikes and Political Radicalism in Sweden and Emigration to the United States." In American Labor and Immigration History, 1877-1920s: Recent European Research, edited by D. Hoerder. Urbana: Univ. Illinois Press.

Thomas, D. S. 1941. Social and Economic Aspects of Swedish Population Movements. New York: Macmillan.

Tuccio, M., J. Wahba, and B. Hamdouch. 2016. "International Migration: Driver of Political and Social Change?” IZA Discussion Paper no. 9794, Inst. Labor Econ., Bonn.

Westerståhl, J. 1945. "Svensk fackföreningsrörelse: Organisationsproblem, verksam hetsformer, förhållande till staten." PhD thesis, Stockholm Univ.

White, G. F., and J. E. Haas. 1975. Assessment of Research on Natural Hazards. Cambridge, MA: MIT Press.

Wilson, J. D. 2011. "Brain-Drain Taxes for Non-benevolent Governments." I. Development Econ. 95 (1): 68-76. 